\title{
Geology-benthos relationships on a temperate rocky bank, eastern Bass Strait, Australia
}

\author{
Robin J. Beaman ${ }^{\mathrm{A}, \mathrm{C}}$, James J. Daniell ${ }^{\mathrm{B}}$ and Peter T. Harris ${ }^{\mathrm{B}}$

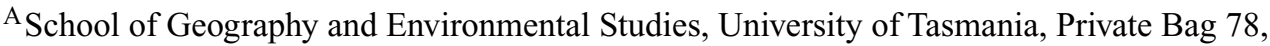 \\ Hobart, Tas. 7001, Australia \\ ${ }^{\mathrm{B}}$ Geoscience Australia, GPO Box 378, Canberra, ACT 2601, Australia. \\ ${ }^{\mathrm{C}}$ Corresponding author. Email: rbeaman@iig.com.au
}

\begin{abstract}
To better understand the possible relationships between the geology of the seabed and the associated biological communities, a multibeam sonar survey over New Zealand Star Bank in the eastern Bass Strait was conducted. A hierarchical method of benthic habitat mapping was applied to the secondary biotope and biological facies levels at the site $(<10 \mathrm{~km})$ scale. Four secondary biotopes and four biological facies have been defined on the basis of geomorphology revealed by the bathymetry model and the results of statistical analysis of the sediment and underwater video transect data over the bank. The major differences that control the distribution of biological communities in the New Zealand Star Bank area appear to be related to variations in substrate. (1) Hard-ground features related to high-relief granite outcrops are associated with diverse and abundant sessile and motile fauna. These faunal communities may be biologically modified to patchy barrens habitat by grazing urchins. (2) Unconsolidated sediment on a flat seabed is associated with sparse small sponges on the inner shelf. On the middle shelf and seaward of bank, the flat and muddy seabed supports a community dominated by infauna. (3) Unconsolidated sediment on a low-relief seabed is associated with an increase in the density and sizes of sponges concentrated on any low-relief feature raised above the surrounding flat seabed.
\end{abstract}

Extra keywords: ecological zonation, GIS, ocean policy.

\section{Introduction}

The south-eastern Australian continental shelf and slope is the location of Australia's oldest fishery and has been the subject of extensive benthic and pelagic surveys to describe the fishhabitat associations (Bax et al. 1999; Bax and Williams 2001; Kloser et al. 2001; Williams and Bax 2001). Recently, this area was included as part of the South-east Regional Marine Plan in support of Australia's Oceans Policy (NOO 2004). A key step in the development of the plan was an assessment of the physical and biological structure of the area and an examination of the processes that link the two components together (Butler et al. 2001). Previous efforts to classify the marine ecosystems of the south-eastern Australian continental shelf were descriptions of bioregions at regional scales of hundreds of kilometres, based primarily on the ranges of fishes in conjunction with physical environmental attributes (IMCRA 1998). At a finer scale, a series of transects across the southeastern shelf, in combination with fishers' information and physical and biological sampling, defined the boundaries of seabed habitats at the local (tens of kilometres) scale (Bax and Williams 2001). Within these transects, (i) soft, (ii) hard and (iii) rough substrate features were examined, and generally related to unconsolidated sand or mud, low-relief limestone or sandstone slabs, and high-relief granite or limestone outcrops respectively (Bax and Williams 2001).

In the present study, we report the detailed seabed mapping of New Zealand Star Bank, a group of granite outcrops on the inner continental shelf of eastern Bass Strait and a noted shipping hazard off the Victoria coast. We define the spatial boundaries of the benthic habitats and biological communities of the area at the site $(<10 \mathrm{~km})$ scale. Our study contributes habitat maps of the area, which has, until now, been poorly mapped and provides a better understanding of the relationships between seabed geology and associated benthic communities. The study was conducted as part of a co-operative survey between Geoscience Australia and the Royal Australian Navy (RAN) aboard the Hydrographic Ship HMAS Melville, and utilised the shallow-water Fansweep20 multibeam sonar (Atlas Hydrographic, Sydney). Geophysical sampling and underwater video data collected in this study reveal a complex bathymetry and biological structure that complements the limited information of marine ecosystems and processes of the eastern Bass Strait. This survey is also timely because New Zealand Star Bank is included within the 'East Gippsland Broad Area of Interest' in the Southeast Regional Marine Plan (NOO 2004). Candidate marine 
protected areas are being investigated within 'Broad Areas of Interest' to ensure a National Representative System of Marine Protected Areas (MPAs; DEH 2003). Because of the difficulty with mapping the distribution of benthic biodiversity, MPAs rely on abiotic factors to characterise the seabed and water column and therefore provide a basis for reserve selection (Stevens 2002; Roff et al. 2003). Thus, an important question is whether geological data can be used as a proxy to predict the occurrence of assemblages of benthic organisms.

To make our results more applicable to the MPA process and help answer this question, we adopted a benthic habitat classification scheme used for the bioregionalisation of Australia (Butler et al. 2001). Habitat can be considered as the place, or type of site, where an organism or population occurs naturally, and can be used as a surrogate for ecological structure in a hierarchical context (NOO 2002). Marine ecosystems vary at a range of nested spatial scales, and the classification scheme developed by Butler et al. (2001) defined the following.

(1) Provinces, in the order of thousands of kilometres in extent, based on broad-scale geological patterns, e.g. continental blocks and abyssal basins.

(2) Biomes, nested within provinces and at scales of hundreds of kilometres, which show broad-scale geomorphology, e.g. coast, continental shelf, slope and abyssal plain.

(3) Geomorphic units, within each biome at the local (tens of kilometres) scale, are areas of similar seafloor geomorphology and which usually have distinct biotas, e.g. seamounts, canyons, sand banks and coral reefs.

(4) Primary biotopes refer to soft, hard and mixed substratebased units, together with their associated floral and faunal communities, also at the local (tens of kilometres) scale. Maps to this level can generally be obtained by high-resolution acoustic surveys.

(5) Secondary biotopes are substructural units within primary biotopes, distinguished by the types of physical or biological substrate within soft, hard or mixed types at the site $(<10 \mathrm{~km})$ scale, e.g. limestone, granite, shelly sands or seagrasses. Maps to this level are provided by biological and physical groundtruth sampling.

(6) Biological facies are identifiable site $(<10 \mathrm{~km})$ scale units defined by a biological indicator, such as a species of seagrass, or group of corals, sponges or other macrofauna adherent to the facies.

This paper presents an interdisciplinary study through the use of geographic information systems (GIS) techniques and mapping of available datasets. This study aims to: $(i)$ define the spatial boundaries of secondary biotopes and biological facies at the site $(<10 \mathrm{~km})$ scale on the basis of geomorphology, surficial sediment composition and the results of underwater video analysis; and (ii) explore the possible relationships between the geology of the seabed and the associated biological communities.

\section{Materials and methods}

\section{Study area}

New Zealand Star Bank is positioned at $37^{\circ} 47^{\prime} \mathrm{S} 149^{\circ} 43^{\prime} \mathrm{E}$ and lies $\sim 10 \mathrm{~km}$ south-east of Little Rame Head on the Victorian East Gippsland coast (Fig. 1a). The bank is made of crystalline, high-relief ( $>1 \mathrm{~m}$ in vertical change) granite that outcrops on the seabed, rising to a minimum depth of $\sim 10 \mathrm{~m}$ (RAN 2002). The granite is an extension of the Lachlan fold belt consisting of a multitude of Silurian-Devonian granites found through eastern New South Wales and Victoria (Coney et al. 1990), and is likely lower Silurian (434-420 million years ago (Mya)) in age, inferred from the similar granite outcrops on the land (DNRE 1999). The shelf in this area is known to contain other granite outcrops, e.g. Point Hicks Reef, but these banks are smaller and closer to the coast. New Zealand Star Bank also lies at the eastern end of an elongate, low-relief $(<1 \mathrm{~m}$ in vertical change) sandstone outcrop, which parallels the East Gippsland coastline and is known as Broken Reef (Fig. 1b). These low-relief slabs of rock are likely Quaternary aeolian dune deposits of sand similar to dune deposits found along the present Gippsland shoreline (DNRE 1999), and possibly formed as sand bodies along palaeo-coastlines (Bax and Williams 2001). These hard substrate features contrast with the surrounding relatively flat seabed of mainly unconsolidated quartz sands with variable amounts of shell debris (Jones and Davies 1983). Seaward of New Zealand Star Bank, the seabed drops steeply to a depth of over $120 \mathrm{~m}$, where muddy quartzose and calcareous sediments extend over the remainder of the shelf to the shelf break.

The bank lies within the Twofold Shelf bioregion, where the climate is moist cool temperate with warm summers and winter-spring rainfall (IMCRA 1998). The near-seabed oceanography in the vicinity of the bank is influenced by coastal trapped wave (CTW) energy that is generated in the Bass Strait and propagates northwards along the eastern Victoria and southern coast of New South Wales (NSW; Morrow et al. 1990; Harris et al. 1991). Coastal trapped waves propagate along the East Gippsland shelf at a speed of $\sim 3.1 \mathrm{~m} \mathrm{~s}^{-1}$ (Morrow et al. 1990) and coincide with the northerly-flowing tongue of $\operatorname{cool}\left(\sim 12^{\circ} \mathrm{C}\right)$ Bass Strait water (Lavering 1994; Bax et al. 2001). In addition, most of the Bass Strait is well mixed vertically due to wind-induced currents. These currents are locally produced and therefore flow in the direction of the wind down to water depths of $\sim 60$ to $70 \mathrm{~m}$ (Middleton and Black 1994). Wave energy is relatively low, but stalled low pressure systems in the Tasman Sea during summer create higher wave energy along the coast (IMCRA 1998), and will only reach the seabed in depths of $100 \mathrm{~m}$ under rare storm events (Harris et al. 1991). Surface water masses in the vicinity of the Gippsland Shelf are influenced by the southern extremity of eddies belonging to the East Australian Current with temperatures of $13^{\circ}$ to $16^{\circ} \mathrm{C}$, which intermittently intrude over the shelf (Bax et al. 2001; Young et al. 2001)

\section{Bathymetry data}

A Fansweep20, $100 \mathrm{kHz}$, multibeam sonar system (Atlas Hydrographic, Sydney, Australia) was used to map the seabed over New Zealand Star Bank, initially with survey line spacing $140 \mathrm{~m}$ apart, and then interlined as the morphology of the seabed was revealed (Fig. 2). With swath width set at four times water depth, $100 \%$ coverage was achieved over the $100-\mathrm{km}^{2}$ area of the bank except for a small gap over the shallowest part of the bank, where rising seas made surveying dangerous in this area. Soundings were reduced to lowest astronomical tide (LAT) using predicted tides at Point Hicks. ASCII XYZ (latitude/longitude/depth) data were extracted from the raw files using CARAIBES seafloor mapping software (IFREMER, Paris, France) and interpolated using ArcInfo 
(a)

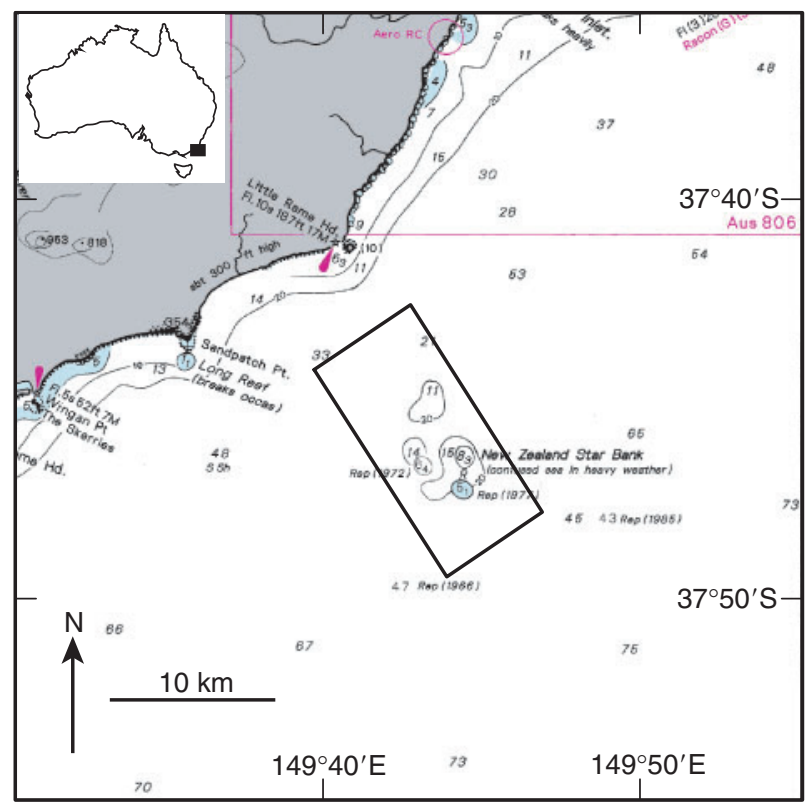

(b)

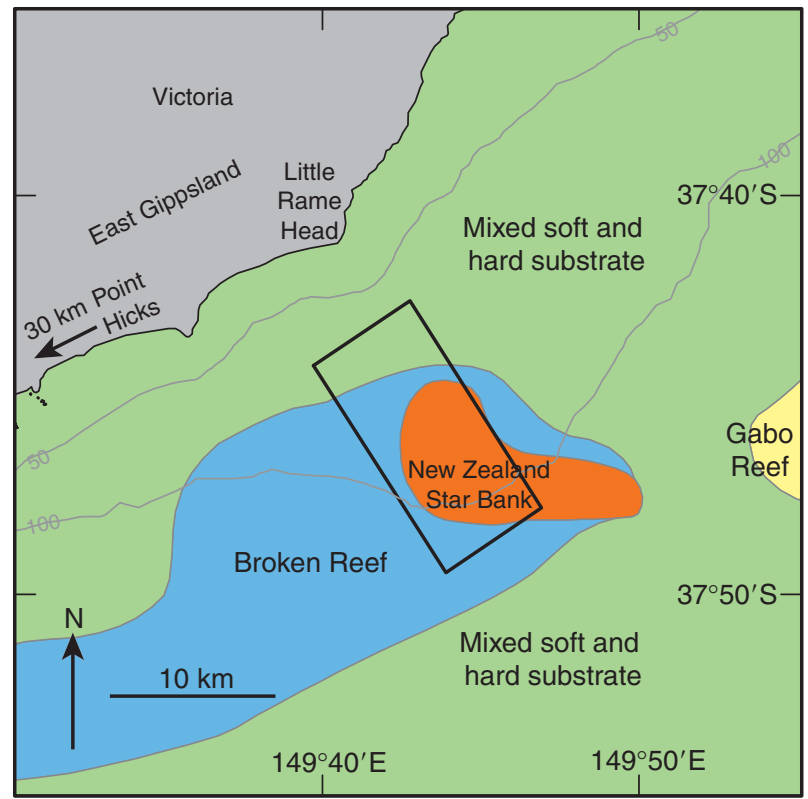

Fig. 1. Mercator projection maps of the study area in eastern Bass Strait off the East Gippsland coast. The box shows the multibeam sonar coverage over New Zealand Star Bank. (a) Continental shelf features from navigation chart AUS358 before the present survey (AHO 1971). Spot depths and contours are in fathoms. The bank was not well defined in previous surveys and posed a significant hazard to shipping. (b) Primary biotopes of the area modified from Bax and Williams (2001), showing the inferred extent of the high-relief granite New Zealand Star Bank next to the low-relief sandstone slabs of Broken Reef. These features lie within mixed soft and hard substrate across the shelf. Depth contours are in metres. Gabo Reef is a high-relief limestone outcrop on the outer shelf.

programme TOPOGRID (ESRI, Redlands, CA) to generate a 5-m resolution bathymetric model. The resulting bathymetry model was analysed for artificial drainage flow and slope within ArcGIS (ESRI), and viewed as a 3D digital terrain model (DTM). CARAIBES was unable to extract the backscatter data from the raw files, and therefore only bathymetry data were used for this study.

\section{Sediment data}

Seabed samples were collected using a Smith-Macintyre grab at nine locations on and around the bank, with most sites sampled twice (Fig. 2 and Table 1). Sediment recovery varied as the water depth increased and weather conditions worsened through the survey, but generally obtained up to $200 \mathrm{~g}$ of material in each grab. The winnowing of finer-grained material out of the grab GR14, in the south of the survey area, led to a rejection of GR14 data for statistical analysis. The grabs GR4 and GR5, with a high sediment volume, were selected for wet sieving into gravel ( $>2 \mathrm{~mm}$ ), sand ( 2 to $0.063 \mathrm{~mm})$ and $\mathrm{mud}(<0.063 \mathrm{~mm})$. The percentages of gravel, sand and mud were recorded as dry weight. The two sediment samples were analysed for mean grain size using a Mastersizer 2000 laser particle sizer (Malvern Instruments, Worcestorshire, UK) and calcium carbonate content was determined as per Harris et al. (2000). These values were compared against previous samples obtained in the vicinity of New Zealand Star Bank from the study by Jones and Davies (1983).

Sediment samples from all the grabs except GR14 were dry sieved and the composition of gravel $(>2 \mathrm{~mm})$ and very coarse sand (1$2 \mathrm{~mm}$ ) fractions were examined under a MZ12 stereozoom microscope (Leitz, Oberkochen, Germany). Where fragments could be clearly identified, they were assigned to various biogenic and lithoclast categories. When a fragment was biogenic but unable to be identified, then it was categorised as unknown bioclast. Composition categories were: coralline algae, coral, polychaete, decapod, gastropod, bivalve, bryozoan, echinoid, unknown bioclast and lithoclast. The weight of the various categories were calculated for each sample, and then standardised into the percentage weight of each sample. Multivariate statistical analysis of sediment composition was undertaken using the PRIMER version 5 software package (Clarke 1993; Clarke and Warwick 2001). Bray-Curtis similarity coefficients were computed on the square-roottransformed percentage weight data to reduce the emphasis on the dominant components. The resulting similarity matrix was analysed using group-averaged cluster analysis, displayed as a dendogram and a non-metric, multi-dimensional scaling (MDS) ordination plot to establish similarity in sediment composition between sites.

\section{Underwater video data}

Underwater video transects were obtained at nine sites selected as being representative of the diverse seabed morphology revealed during the survey (Fig. 2 and Table 2). On average, two minutes was recorded at each site over a transect distance of $100 \mathrm{~m}$ at water depths of between 46 to $120 \mathrm{~m}$. Differential GPS position was recorded automatically as an overlay on the video. At every 2 -s interval, the video transects were classified into environmental descriptors of: (1) substratum (mud, fine sediments, coarse sediments, gravel/pebble, cobble/boulder, igneous/metamorphic rock); (2) geomorphology (unrippled, current rippled, wave rippled, irregular, debris flow/rubble, mounds/pits, subcrop, low $(<1 \mathrm{~m})$ outcrop, high ( $>1 \mathrm{~m}$ ) outcrop); and (3) fauna (none, large/dense sponges, small/sparse sponges, mixed gardens, octocorals, small encrusters/erect forms, sedentary, mobile, bioturbators). Not all environmental descriptors were observed in the underwater video. The resolution of the video data precluded identification of fauna to a lower taxonomic level. The descriptors were mapped within ESRI ArcGIS as point shapefiles for draping on the 3D DTM. Counts were made of each substratum, geomorphology and fauna descriptor present, then 


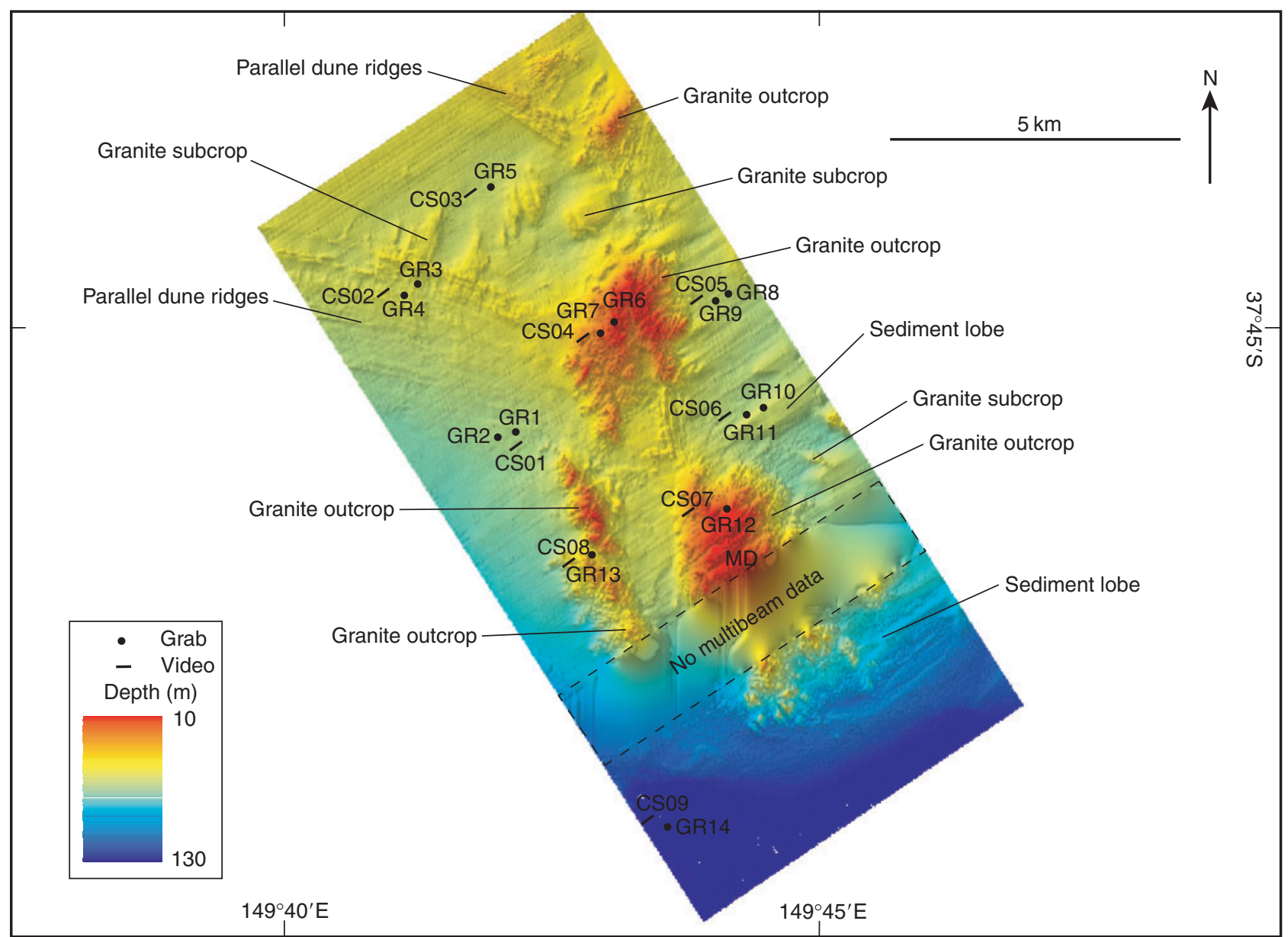

Fig. 2. Shaded relief map of the New Zealand Star Bank bathymetry model at $5 \mathrm{~m}$ resolution and with grab and underwater video transect locations. MD refers to the position of the minimum depth $(\sim 10 \mathrm{~m})$ on the largest granite outcrop.

standardised into the percentage occurrence within each transect. Using PRIMER, a principal component analysis (PCA) was conducted on the untransformed descriptors to establish similarities in the environmental variables across the study area. Principal components analysis ordination using Euclidean distance to measure dissimilarity of samples is a suitable method of analysing relationship trends for environmental variables (Clarke 1993).

An examination of the geomorphology revealed by the bathymetry model and the results of statistical analysis of the sediment and video transect data were used to derive maps of the secondary biotopes and biological facies of the study area.

\section{Results}

\section{Geomorphology}

The geomorphic features shown in Fig. 2 are: (1) the highrelief granite outcrops of New Zealand Star Bank; (2) the lowrelief parallel dune ridges of Broken Reef; (3) sediment lobes to the east of the granite outcrops; and (4) low-relief granite subcrop in patches around the high-relief granite outcrop. The five distinct outcrops of granite reveal a mostly high-relief ( $>1 \mathrm{~m}$ of vertical relief) and structurally complex surface of
Table 1. Grab sample locations and water depth data See Fig. 2 for locations

\begin{tabular}{lccc}
\hline Grab number & Latitude & Longitude & Water depth $(\mathrm{m})$ \\
\hline GR1 & $37^{\circ} 45.8^{\prime} \mathrm{S}$ & $149^{\circ} 42.1^{\prime} \mathrm{E}$ & 74.79 \\
GR2 & $37^{\circ} 45.89^{\prime} \mathrm{S}$ & $149^{\circ} 41.91^{\prime} \mathrm{E}$ & 76.21 \\
GR3 & $37^{\circ} 44.71^{\prime} \mathrm{S}$ & $149^{\circ} 41.23^{\prime} \mathrm{E}$ & 67.39 \\
GR4 & $37^{\circ} 44.74^{\prime} \mathrm{S}$ & $149^{\circ} 41.08^{\prime} \mathrm{E}$ & 68.01 \\
GR5 & $37^{\circ} 43.99^{\prime} \mathrm{S}$ & $149^{\circ} 41.91^{\prime} \mathrm{E}$ & 70.49 \\
GR7 & $37^{\circ} 45.06^{\prime} \mathrm{S}$ & $149^{\circ} 42.93^{\prime} \mathrm{E}$ & 41.23 \\
GR8 & $37^{\circ} 44.73^{\prime} \mathrm{S}$ & $149^{\circ} 44.21^{\prime} \mathrm{E}$ & 70.14 \\
GR9 & $37^{\circ} 44.76^{\prime} \mathrm{S}$ & $149^{\circ} 44.13^{\prime} \mathrm{E}$ & 70.69 \\
GR10 & $37^{\circ} 45.62^{\prime} \mathrm{S}$ & $149^{\circ} 44.47^{\prime} \mathrm{E}$ & 71.39 \\
GR11 & $37^{\circ} 45.67^{\prime} \mathrm{S}$ & $149^{\circ} 44.33^{\prime} \mathrm{E}$ & 72.99 \\
GR12 & $37^{\circ} 46.37^{\prime} \mathrm{S}$ & $149^{\circ} 44.15^{\prime} \mathrm{E}$ & 36.92 \\
GR13 & $37^{\circ} 46.79^{\prime} \mathrm{S}$ & $149^{\circ} 42.86^{\prime} \mathrm{E}$ & 50.87 \\
GR14 & $37^{\circ} 40.83^{\prime} \mathrm{S}$ & $149^{\circ} 43.51^{\prime} \mathrm{E}$ & 125.96 \\
\hline
\end{tabular}

numerous fractures and joints that make up the rocky bank. The outcrops rise from a surrounding seabed of between $60 \mathrm{~m}$ to the north and $120 \mathrm{~m}$ to the south of the bank. The majority of the granite outcrop upper surfaces are between 30 and $40 \mathrm{~m}$ 
Table 2. Underwater video transect locations, water depth and descriptions See Fig. 2 for locations

\begin{tabular}{|c|c|c|c|c|c|c|}
\hline $\begin{array}{l}\text { Video } \\
\text { number }\end{array}$ & $\begin{array}{l}\text { Latitude } \\
\text { start }\end{array}$ & $\begin{array}{l}\text { Longitude } \\
\text { start }\end{array}$ & $\begin{array}{l}\text { Latitude } \\
\text { end }\end{array}$ & $\begin{array}{l}\text { Latitude } \\
\text { end }\end{array}$ & $\begin{array}{l}\text { Water } \\
\text { depth }(\mathrm{m})\end{array}$ & Description \\
\hline $\mathrm{CS} 01$ & $37^{\circ} 45.89^{\prime} \mathrm{S}$ & $149^{\circ} 42.12^{\prime} \mathrm{E}$ & $37^{\circ} 45.91^{\prime} \mathrm{S}$ & $149^{\circ} 42.09^{\prime} \mathrm{E}$ & 74.88 & $\begin{array}{l}\text { Gravel and shell hash, irregular seabed, fauna is sparse, } \\
\text { occasional small erect sponge and bryozoa }\end{array}$ \\
\hline $\mathrm{CS} 02$ & $37^{\circ} 44.78^{\prime} \mathrm{S}$ & $149^{\circ} 40.86^{\prime} \mathrm{E}$ & $37^{\circ} 44.78^{\prime} \mathrm{S}$ & $149^{\circ} 40.83^{\prime} \mathrm{E}$ & 66.92 & $\begin{array}{l}\text { Gravel and shell hash, patchy fauna with initially little fauna } \\
\text { then garden of large erect sponges on irregular seabed }\end{array}$ \\
\hline $\mathrm{CS} 03$ & $37^{\circ} 44.04^{\prime} \mathrm{S}$ & $149^{\circ} 41.75^{\prime} \mathrm{E}$ & $37^{\circ} 44.04^{\prime} \mathrm{S}$ & $149^{\circ} 41.71^{\prime} \mathrm{E}$ & 70.33 & $\begin{array}{l}\text { Gravel and shell hash, irregular seabed with pockets of } \\
\text { New Zealand screw shell, fauna is sparse with small } \\
\text { erect sponges }\end{array}$ \\
\hline $\mathrm{CS} 04$ & $37^{\circ} 45.11^{\prime} \mathrm{S}$ & $149^{\circ} 42.81^{\prime} \mathrm{E}$ & $37^{\circ} 45.13^{\prime} \mathrm{S}$ & $149^{\circ} 42.77^{\prime} \mathrm{E}$ & 46.49 & $\begin{array}{l}\text { High-relief granite outcrop, dense gardens of erect and } \\
\text { encrusting sponges, numerous crinoids and occasional } \\
\text { urchins }\end{array}$ \\
\hline CS05 & $37^{\circ} 44.80^{\prime} \mathrm{S}$ & $149^{\circ} 43.94^{\prime} \mathrm{E}$ & $37^{\circ} 44.81^{\prime} \mathrm{S}$ & $149^{\circ} 43.90^{\prime} \mathrm{E}$ & 69.69 & $\begin{array}{l}\text { Shell hash and rubble, irregular seabed, large erect sponges } \\
\text { occur on rougher seabed, isolated small sponges occur on } \\
\text { sediment flat }\end{array}$ \\
\hline CS06 & $37^{\circ} 45.73^{\prime} \mathrm{S}$ & $149^{\circ} 44.11^{\prime} \mathrm{E}$ & $37^{\circ} 45.74^{\prime} \mathrm{S}$ & $149^{\circ} 44.06^{\prime} \mathrm{E}$ & 73.12 & $\begin{array}{l}\text { Shell hash and rubble, irregular seabed and granite } \\
\text { boulders, large sponges on seabed, dense sponge } \\
\text { gardens on granite boulders }\end{array}$ \\
\hline $\mathrm{CS} 07$ & $37^{\circ} 46.45^{\prime} \mathrm{S}$ & $149^{\circ} 43.82^{\prime} \mathrm{E}$ & $37^{\circ} 46.48^{\prime} \mathrm{S}$ & $149^{\circ} 43.71^{\prime} \mathrm{E}$ & 49.83 & $\begin{array}{l}\text { Low-relief granite outcrop and shell hash seabed, granite } \\
\text { with small sponges and sea whips, or dense in black } \\
\text { sea urchins }\end{array}$ \\
\hline $\mathrm{CS} 08$ & $37^{\circ} 46.78^{\prime} \mathrm{S}$ & $149^{\circ} 42.70^{\prime} \mathrm{E}$ & $37^{\circ} 46.81^{\prime} \mathrm{S}$ & $149^{\circ} 42.64^{\prime} \mathrm{E}$ & 62.92 & $\begin{array}{l}\text { High-relief granite outcrop and shell hash, dense sponge } \\
\text { and octocoral gardens on granite, little sessile fauna } \\
\text { on sediment }\end{array}$ \\
\hline CS09 & $37^{\circ} 48.98^{\prime} \mathrm{S}$ & $149^{\circ} 43.23^{\prime} \mathrm{E}$ & $37^{\circ} 49.01^{\prime} \mathrm{S}$ & $149^{\circ} 43.17^{\prime} \mathrm{E}$ & 120.1 & $\begin{array}{l}\text { Unrippled, coarse well sorted sediment, shell hash, fauna } \\
\text { very sparse, rare octocorals, occasional burrows in seabed }\end{array}$ \\
\hline
\end{tabular}

depth, whereas only the larger outcrop to the south rises to the minimum depth of $\sim 10 \mathrm{~m}$ (marked as MD in Fig. 2).

To the north-west of the survey area are parallel dune ridges. These are the low-relief ( $<1 \mathrm{~m}$ vertical relief) features of Broken Reef, appearing as two discrete bands of linear, parallel dune ridges. One band is $\sim 2000 \mathrm{~m}$ in width and the second is $400 \mathrm{~m}$ in width, and they abut the northern granite outcrops in depths of between 65 and $75 \mathrm{~m}$. Dune ridge crests average $\sim 70 \mathrm{~m}$ apart and between 0.25 and $1.25 \mathrm{~m}$ from crest to trough in height. The ridge crests appear to be highly eroded and are structurally less complex than the high-relief granite outcrops, but most ridges can be followed continuously for over $5 \mathrm{~km}$ across the area surveyed.

On the eastern side of the granite outcrops are smooth and mounded features 2 to $3 \mathrm{~m}$ high that stretch linearly in a northeasterly direction away from the rocky bank. These appear to be sediment lobes of soft unconsolidated sediment forming in the lee of the granite outcrops. Clustered around the high-relief outcrops is granite subcrop, defined as low-relief ( $<1 \mathrm{~m}$ vertical relief) granite that influences the morphology of the seabed, which is composed of soft unconsolidated substrate. Granite subcrop appears as small areas of raised seabed between the high-relief granite outcrops and parallel dune ridges and also among the sediment lobes. The remaining seabed around these geomorphic features appears as flat and unrippled unconsolidated soft substrate.

\section{Surficial sediment}

The results of the laser particle sizer on samples GR4 and GR5 show both are unimodal, medium to coarse sand, with less than 1\% mud. The percentage gravel of GR4 and GR5 are $14.6 \%$ and $11.36 \%$ respectively. The gravel fractions are dominated by broken and abraded bioclasts, and rounded and iron-stained quartz granules. Minor bioclastic components are modern disarticulated bivalves, broken gastropods and bryozoan pieces. A comparison of the mean grain sizes of the samples GR4 and GR5 with the Jones and Davies (1983) samples BMR1785, BMR1786 and BMR1790, reveals a coarsening of sediments in proximity to the bank (Fig. 3). Despite the approximate 20-year difference between sample times, we do not believe that the hydrodynamic conditions have changed so much as to result in a uniform coarsening across the shelf, and so the coarse sediments found in the present study are more directly related to proximity to the rocky bank. Classification of the samples using the Folk (1954) scheme shows that both GR4 and GR5 are a gravelly sand, whereas BMR1785 and BMR1790 are slightly gravelly sand, and BMR1786 is slightly gravelly, muddy sand. The mean grain size for BMR1786 shows an increase in finergrained material seaward of the bank and in the deeper water found south-east of the survey area.

A comparison of the calcium carbonate content from GR4 and GR5 shows they are similar to, or slightly less than, the 
adjacent BMR samples (Fig. 3). Sample BMR1786 shows an increase in carbonate content south-east of the bank. In addition, a microscope examination of the sand and gravel fractions from all grab samples obtained in the present study revealed interesting patterns for the non-biogenic material across the survey area. In samples obtained on the parallel dune ridges to the north-west, the non-biogenic material is mostly rounded and iron-stained quartz grains with minor, medium-grained quartz sandstone fragments (Fig. 3). We believe the sandstone fragments confirm that Broken Reef was formed from aeolian coastal dunes (Jones and Davies 1983), and that the sandstone is being eroded and reworked into the thin unconsolidated soft sediments overlying the dune ridges. In the south-west study area, only rounded and ironstained quartz particles are found, whereas quartz and mafic

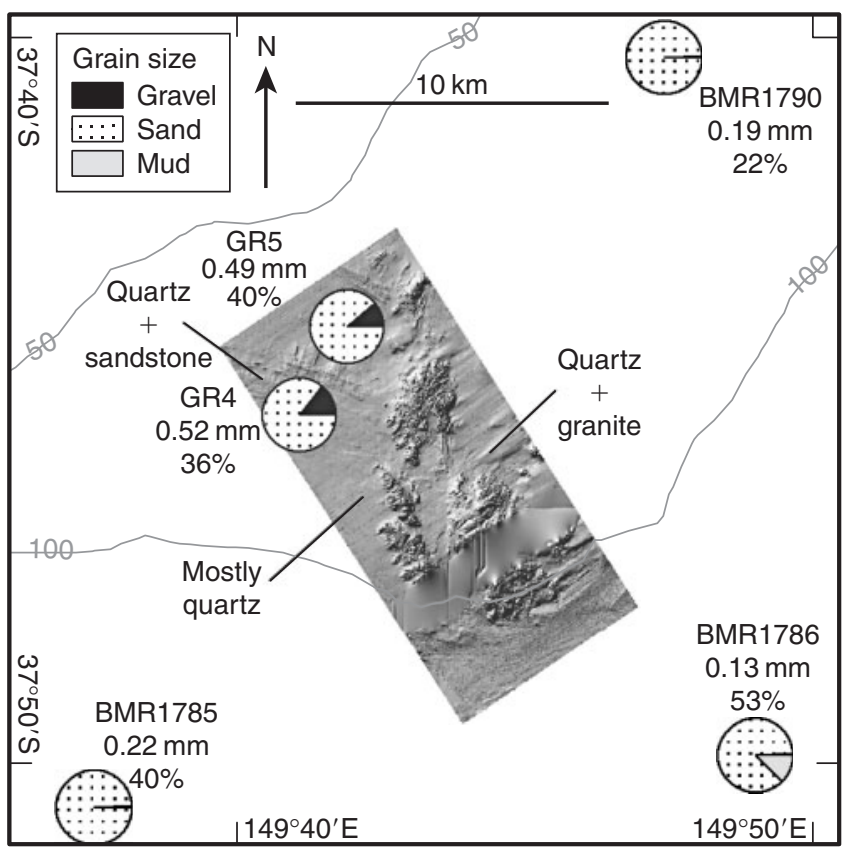

Fig. 3. Gravel, sand and mud proportions for GR4 and GR5 compared with previous samples obtained by Jones and Davies (1983). The samples names are followed by mean grain size $(\mathrm{mm})$, then the calcium carbonate percentage of each sample. mineral fragments commonly found in granite are found north-east of the granite outcrops. This pattern of mostly quartz to the south-west and quartz and mafic mineral fragments to the north-east is consistent with sediment transport by the prevailing north-easterly-flowing current over New Zealand Star Bank, which deposit eroded granite particles and create the sediment lobes on the leeward side of the bank (Fig. 2).

The percentage weight of sediment composition in the combined gravel and very coarse sand fractions $(>1 \mathrm{~mm})$ are listed in Table 3. Multivariate statistical analysis of this dataset reveals division into two groups (Fig. $4 a, b$ ). The presence of coralline algae only within samples GR7 and GR12, results in the other samples appearing to cluster together (Fig. 4b). These two samples were obtained directly from the high-relief granite outcrops with a high coverage of benthos, with the remaining samples collected from mostly unconsolidated soft substrate around the bank. A solution to observing the trends in soft substrate composition around New Zealand Star Bank is to split the data and conduct ordination separately on just the soft substrate samples after square-root-transformation (Fig. $4 c, d$ ). In Fig. $4 d$, most samples have a high level of similarity except for GR4 and GR13. Sample GR4 was obtained from the crest of the parallel dune ridges of Broken Reef in the north-west of the survey area and has high lithoclast content. Sample GR13 was obtained from a narrow channel between the two westerly granite outcrops, and has low lithoclast content, as might be expected for a sample obtained proximal to granite outcrop with a high coverage of benthos.

\section{Environmental variables}

The percentage occurrence of substratum, geomorphology and fauna descriptors from the nine underwater video transects are listed in Table 4. Principal components analysis of this dataset reveals division into three groups (Fig. 5a,b). There is a clear trend of transects separating a group comprising the granite outcrop sites (CS04, CS07 and CS08) from a group of sites collected over the soft substrate around New Zealand Star Bank (CS01, CS02, CS03, CS05 and CS06). The high proportion of gravelly sand observed in the latter group

Table 3. The percentage weight of sediment composition for grains $>1 \mathrm{~mm}$

\begin{tabular}{|c|c|c|c|c|c|c|c|c|c|c|c|c|}
\hline Grab number & GR1 & GR2 & GR3 & GR4 & GR5 & GR7 & GR8 & GR9 & GR10 & GR11 & GR12 & GR13 \\
\hline Coral algae (\%) & 0.00 & 0.00 & 0.00 & 0.00 & 0.00 & 65.46 & 0.00 & 0.00 & 0.00 & 0.00 & 87.02 & 0.00 \\
\hline Coral (\%) & 0.00 & 0.00 & 0.00 & 0.00 & 0.00 & 0.00 & 1.75 & 0.00 & 0.00 & 0.06 & 0.00 & 0.00 \\
\hline Polychaete (\%) & 0.62 & 0.43 & 0.40 & 0.24 & 0.54 & 0.90 & 3.45 & 4.53 & 3.00 & 0.22 & 0.67 & 1.09 \\
\hline Decapod (\%) & 0.00 & 0.02 & 0.00 & 0.00 & 0.00 & 0.00 & 1.68 & 0.08 & 0.09 & 0.04 & 0.38 & 1.12 \\
\hline Gastropod (\%) & 11.62 & 4.13 & 4.95 & 2.11 & 2.25 & 0.00 & 3.16 & 2.23 & 2.93 & 3.48 & 3.24 & 6.32 \\
\hline Bivalve (\%) & 2.24 & 1.30 & 6.88 & 9.60 & 2.22 & 1.03 & 3.93 & 1.86 & 2.34 & 5.08 & 2.77 & 1.44 \\
\hline Bryozoa (\%) & 3.47 & 2.91 & 7.01 & 2.24 & 3.98 & 10.50 & 12.44 & 20.66 & 9.18 & 9.12 & 2.19 & 38.45 \\
\hline Echinoid (\%) & 0.32 & 0.17 & 1.12 & 0.28 & 0.00 & 0.00 & 0.05 & 0.48 & 1.18 & 2.30 & 0.00 & 0.90 \\
\hline Bioclast (\%) & 48.24 & 46.93 & 42.30 & 28.73 & 54.92 & 12.24 & 38.34 & 31.21 & 47.19 & 38.84 & 0.86 & 35.35 \\
\hline Lithoclast (\%) & 33.50 & 44.11 & 37.34 & 56.80 & 36.09 & 9.86 & 35.20 & 38.94 & 34.09 & 40.85 & 2.86 & 15.32 \\
\hline
\end{tabular}


confirm that surficial sediments landward of New Zealand Star Bank are from the inner shelf (Jones and Davies 1983). Seaward of New Zealand Star Bank, the transect CS09 was collected in $\sim 120 \mathrm{~m}$ of water and is dissimilar to the other transects due to the increased presence of bioturbators (e.g. burrows) observed in the video. The high proportion of finergrained sediments observed in CS09 compared with the other transects confirms that this site lies in the middle shelf where muddy sand dominates (Jones and Davies 1983).

This simplified visualisation of similarities (dissimilarities) between the environmental variables observed in transects belies the complexity of faunal-geologic relationships revealed by underwater video. For example, graphs of the numbers of small and large sponges, mobile fauna (e.g. crinoids and black sea urchins) and sea whips observed at two second intervals along soft substrate transects (Fig. 6a,b), and along granite outcrop transects (Fig. $6 c, d$ ), shows that the high-relief outcrops are associated with a relatively greater abundance and diversity of fauna than flat or low-relief habitats. Transect CS02 (Fig. 6a) was obtained over the parallel dune ridges to the north-west, and initially reveals a relatively flat seabed of shell hash with sparse large sponges as sessile fauna, which coincides with a trough. The video proceeds onto a shell hash-covered, rough and irregular seabed coinciding with a crest. At this point, a distinct patch of dense and erect large sponges appears. Transect CS06 (Fig. 6b) was obtained in the eastern part of the study area among a flat or irregular seabed covered in shell hash with the occasional rounded granite boulder protruding through the soft substrate. The majority of the flat seabed has a fauna of small erect sponges. However, wherever a boulder appears through the soft substrate, both large and small sponges cluster on the rock.

In contrast to transects obtained over flat or low-relief soft substrate environments, the fauna of the CS04 (Fig. 6c) transect obtained over a high-relief granite outcrop is a dense coverage of large and small sponges, and scattered individuals of mobile fauna, such as crinoids and urchins hiding in the numerous cracks and crevices. To show that not all granite outcrop is densely covered in sponges, the transect CS07 (Fig. $6 d$ ) reveals large numbers $\left(\sim 10\right.$ to $\left.14 \mathrm{~m}^{-2}\right)$ of the black sea urchin (Centrostephanus rodgersii) apparently (a)

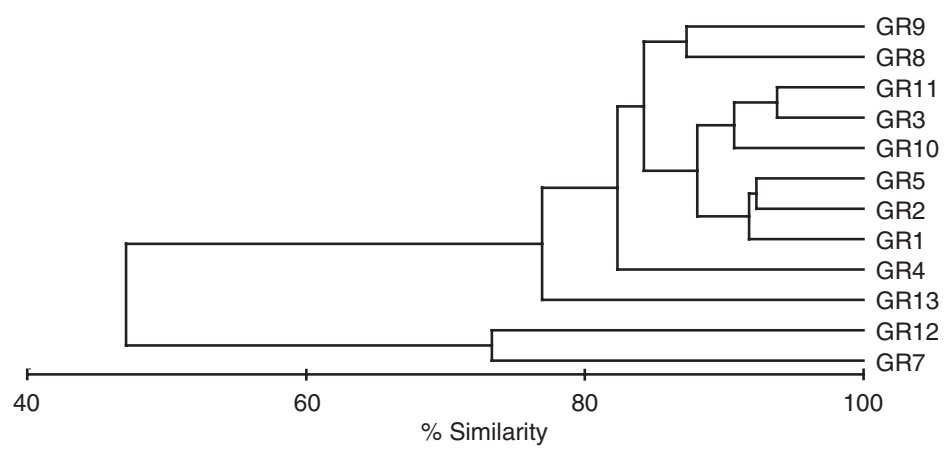

(c)

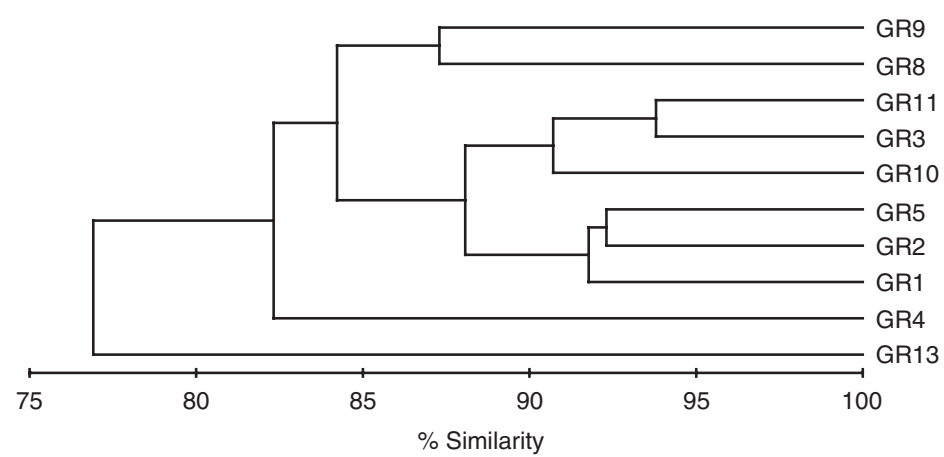

(b)

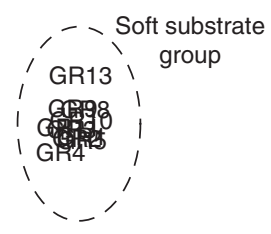

$(d)$

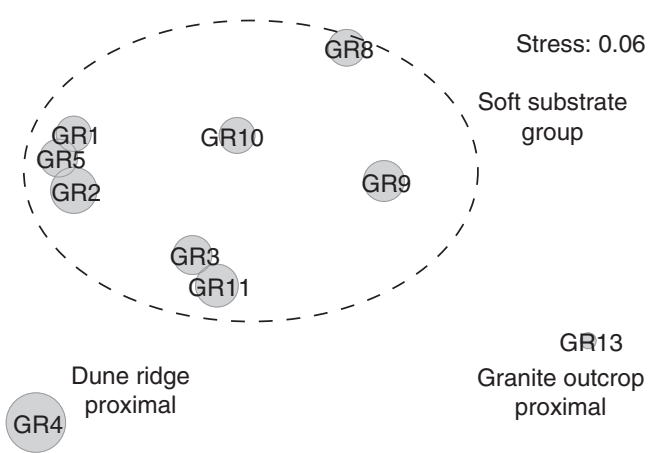

Fig. 4. (a) Group-averaged dendogram of cluster analysis on the square-root-transformed percentage weight of sediment composition for the samples in Table 3. (b) Two-dimensional ordination plot from non-metric multi-dimensional scaling (MDS) of all samples, showing the relative size of coralline algae percentage weight. The samples are clustered into two groups due to the presence of coralline algae only in the two granite outcrop samples GR7 and GR12. The stress value is low, emphasising a good representation of the ordination. (c) Group-averaged dendogram of cluster analysis on the square-root-transformed percentage weight of the composition from just the soft substrate samples, i.e. samples GR7 and GR12 removed. $(d)$ MDS plot of just the soft substrate samples, showing the relative size of lithoclast percentage weight. Most samples are similar within the soft substrate group. GR4 was obtained over Broken Reef and has high lithoclast content. GR13 was obtained proximal to granite outcrop with a high coverage of benthos and has low lithoclast content. 
Table 4. Underwater video transect—-substratum, geomorphology and fauna descriptors for the nine video transects Counts were made of the various descriptors at two second intervals along each transect and standardised into percentage occurrence

\begin{tabular}{|c|c|c|c|c|c|c|c|c|c|c|}
\hline \multicolumn{6}{|c|}{ Substratum } & \multicolumn{5}{|c|}{ Geomorphology } \\
\hline $\begin{array}{l}\text { Video } \\
\text { number }\end{array}$ & $\begin{array}{c}\text { Coarse } \\
\text { sediment (\%) }\end{array}$ & \multicolumn{2}{|c|}{$\begin{array}{c}\text { Gravel/pebble } \\
(\%)\end{array}$} & \multicolumn{2}{|c|}{$\begin{array}{l}\text { Igneous } \\
\text { rock (\%) }\end{array}$} & \multicolumn{2}{|c|}{$\begin{array}{l}\text { Unrippled } \\
(\%)\end{array}$} & $\begin{array}{l}\text { Irregular } \\
(\%)\end{array}$ & $\begin{array}{c}\text { Low } \\
\text { outcrop (\%) }\end{array}$ & $\begin{array}{c}\text { High } \\
\text { outcrop (\%) }\end{array}$ \\
\hline $\mathrm{CS} 01$ & 0.00 & & & & & & & 100.00 & 0.00 & 0.00 \\
\hline $\mathrm{CS} 02$ & 0.00 & & & & & & & 27.59 & 0.00 & 0.00 \\
\hline $\mathrm{CS} 03$ & 0.00 & & & & & & & 37.50 & 0.00 & 0.00 \\
\hline CS04 & 0.00 & & & & & & & 0.00 & 58.18 & 41.82 \\
\hline $\mathrm{CS} 05$ & 0.00 & & & & & & & 57.69 & 0.00 & 0.00 \\
\hline CS06 & 0.00 & & & & & & & 68.89 & 0.00 & 11.11 \\
\hline CS07 & 0.00 & & & & & & & 33.33 & 63.89 & 2.78 \\
\hline CS08 & 0.00 & & & & & & & 4.69 & 14.06 & 46.88 \\
\hline \multirow[t]{2}{*}{ CS09 } & 100.00 & & & & & & & 0.00 & 0.00 & 0.00 \\
\hline & \multicolumn{10}{|c|}{ Fauna } \\
\hline $\begin{array}{l}\text { Video } \\
\text { number }\end{array}$ & $\begin{array}{l}\text { No fauna } \\
(\%)\end{array}$ & $\begin{array}{c}\text { Large } \\
\text { sponge (\%) }\end{array}$ & $\begin{array}{r}\mathrm{S} 1 \\
\text { spon }\end{array}$ & & & & $\begin{array}{c}\text { Octocoral } \\
(\%)\end{array}$ & $\begin{array}{c}\text { Encruster } \\
(\%)\end{array}$ & $\begin{array}{l}\text { Mobile } \\
(\%)\end{array}$ & $\begin{array}{c}\text { Bioturbator } \\
(\%)\end{array}$ \\
\hline CS01 & 73.68 & 0.00 & & & & & 0.00 & 5.26 & 0.00 & 0.00 \\
\hline CS02 & 6.90 & 37.93 & & & & & 0.00 & 0.00 & 0.00 & 0.00 \\
\hline $\mathrm{CS} 03$ & 65.00 & 5.00 & & & & & 0.00 & 0.00 & 0.00 & 0.00 \\
\hline CS04 & 0.00 & 58.18 & & & & & 0.00 & 10.91 & 25.45 & 0.00 \\
\hline CS05 & 57.69 & 13.46 & & & & & 0.00 & 0.00 & 3.85 & 0.00 \\
\hline CS06 & 26.67 & 17.78 & & & & & 0.00 & 2.22 & 0.00 & 0.00 \\
\hline CS07 & 2.78 & 0.00 & & & & & 0.00 & 0.00 & 32.41 & 0.00 \\
\hline CS08 & 34.38 & 37.50 & & & & & 0.00 & 0.00 & 0.00 & 0.00 \\
\hline CS09 & 84.21 & 0.00 & & & & & 3.51 & 0.00 & 0.00 & 12.28 \\
\hline
\end{tabular}

(a)

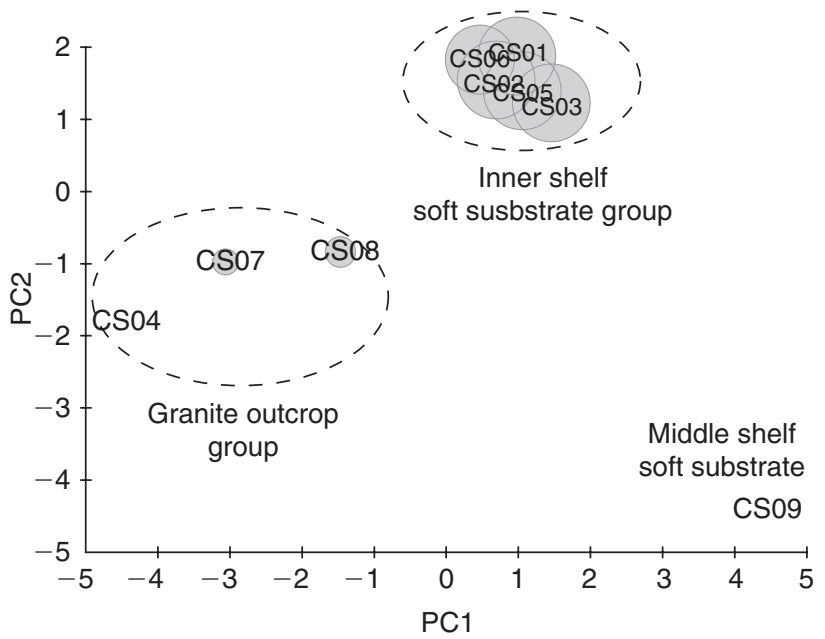

(b)

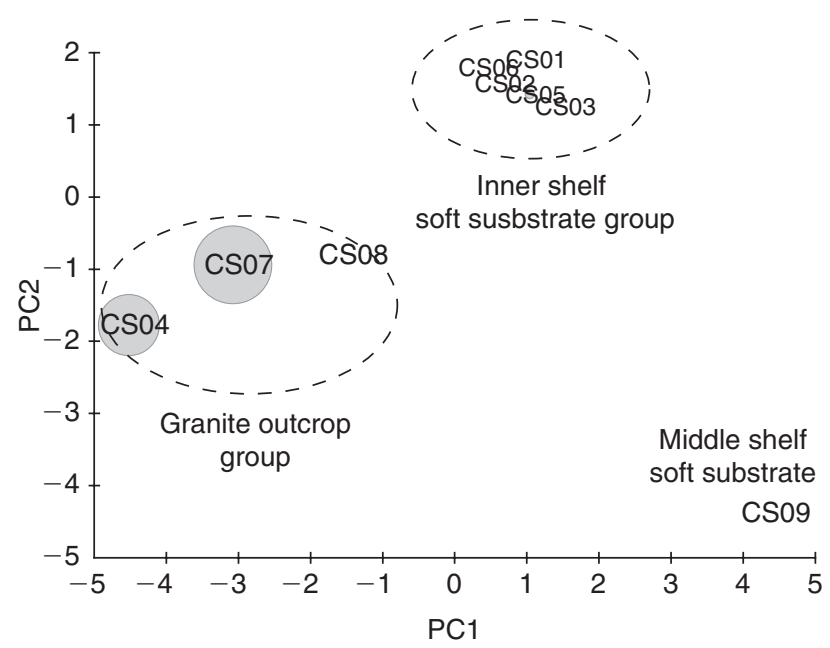

Fig. 5. (a) Ordination plot of principal component analysis (PCA) using Euclidean distance on untransformed substratum, geomorphology and fauna descriptors in Table 4, showing the relative size of gravel/pebble percentage occurrence. $(b)$ Ordination plot of PCA of the descriptors in Table 4, showing the relative size of mobile fauna percentage occurrence. The samples are clustered into three groups due partly to the high presence of gravel/pebble in the inner shelf soft substrate group and the presence of mobile fauna and igneous rock observed in the granite outcrop group.

grazing low-relief granite outcrop so that few sessile fauna are present. Wherever urchins are absent or sparse, small sponges and sea whips (Primnoella australasiae) occur. Interspersed between the granite outcrops is a flat seabed of shell hash sediment, where fauna numbers typically drop. A pattern is repeated throughout the survey of sparse small sponges occurring on relatively flat seabed of unconsolidated soft sediments, with patches of large sponges appearing wherever the seabed has low-relief or where rounded granite boulders protrude through the sediment. Wherever the seabed 

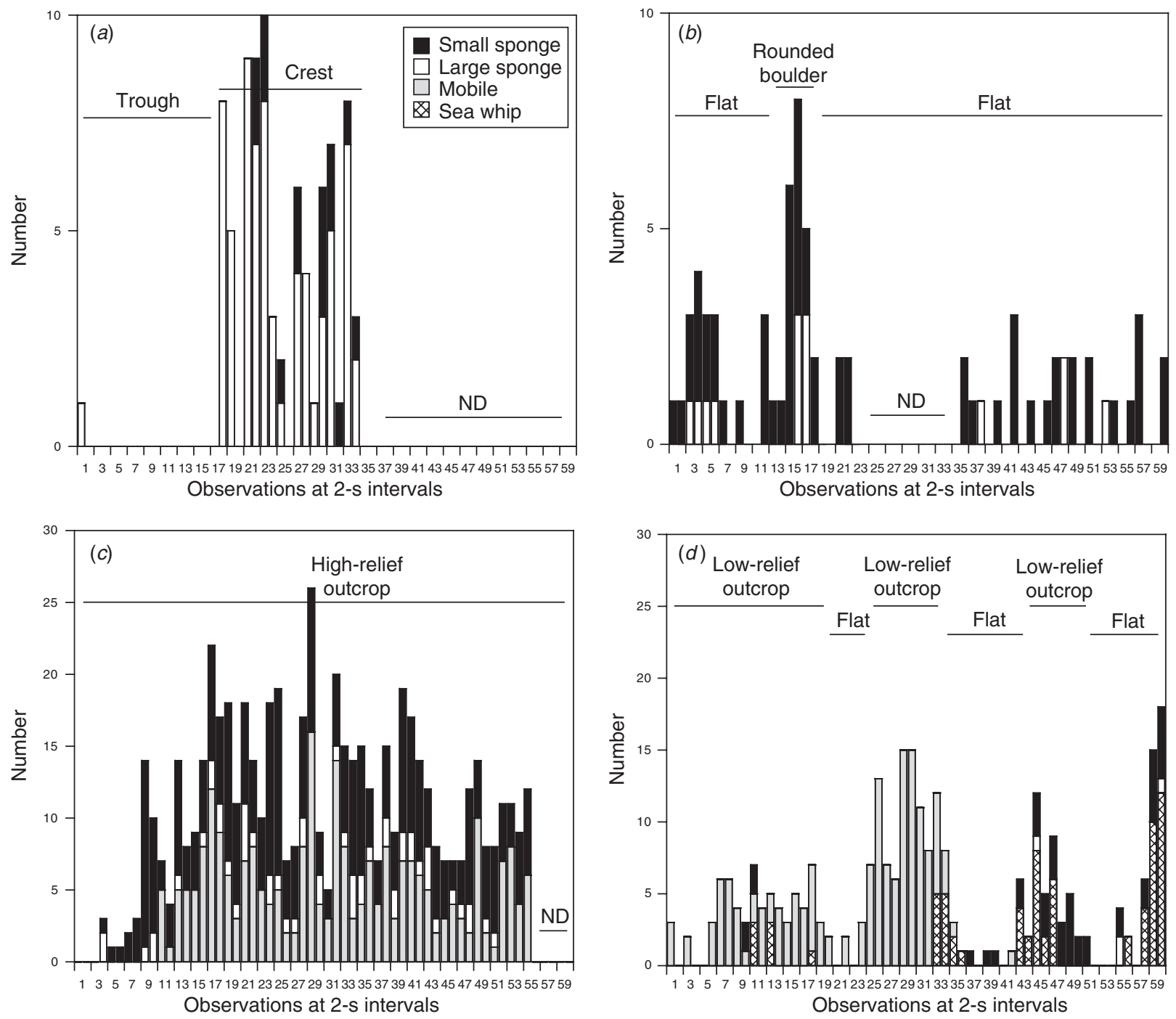

Fig. 6. Distribution of the numbers of small and large sponges, mobile fauna (e.g. crinoids and black sea urchins) and sea whips observed at 2-s intervals along video transects. Soft substrate transects: $(a)$ CS02 and (b) CS06. Granite outcrop transects: $(c)$ CS04 and $(d)$ CS07. See Fig. 2 for locations. ND denotes no data.

comprises high-relief granite outcrop with a structurally complex surface, dense mixed sponge gardens appear.

\section{Secondary biotopes and biological facies}

Through an examination of the geomorphology, surficial sediment characteristics and results of the video transect analysis, the study area was divided into four secondary biotopes and four biological facies at the site $(<10 \mathrm{~km})$ scale, showing a high correlation between the predominant types of physical substrate observed and the biological communities associated with this substrate (Fig. 7). We believe that the patterns observed using the available datasets support the spatial boundaries of the mapped units within the context and scales of the hierarchical classification scheme developed by Butler et al. (2001). A description of each secondary biotope and the corresponding biological facies is given, which provides insights into the possible relationships between the geology of the seabed and the associated biological communities. A conceptual model of New Zealand Star Bank area is shown in Fig. 8.

\section{'High-relief granite' and 'deep reef/urchin barrens'}

The 'high-relief granite' secondary biotope clearly stands out from the surrounding low-relief or flat seabed in the bathymetric model as five discrete outcrops. The numerous fractures and joints give the granite outcrop surfaces a rough appearance in the model. These outcrops have upper surfaces of between $\sim 30$ and $40 \mathrm{~m}$ water depth, and the larger granite outcrop reaches a minimum depth of $\sim 10 \mathrm{~m}$. Underwater video reveals that not all the rocky bank outcrop is highrelief ( $>1 \mathrm{~m}$ in vertical change) granite. At the margins of the outcrops are found rounded granite boulders of low-relief 


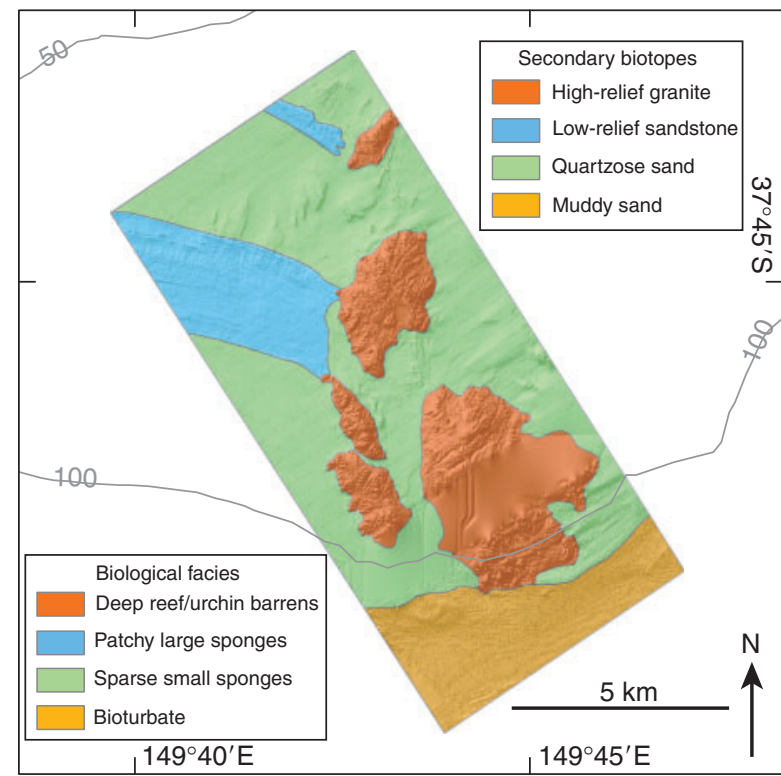

Fig. 7. Secondary biotopes and biological facies of the study area.

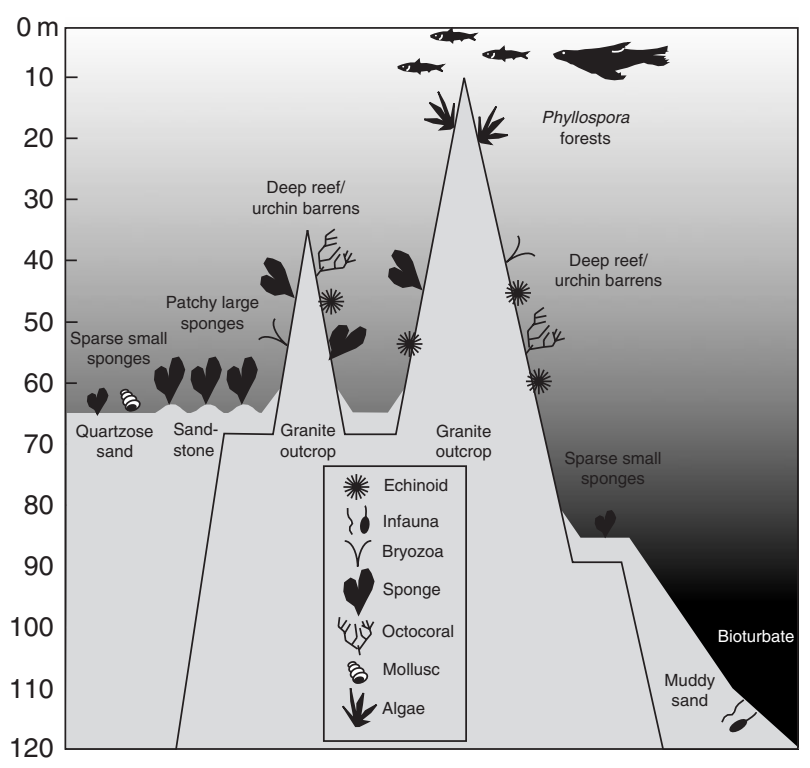

Fig. 8. New Zealand Star Bank conceptual model.

( $<1 \mathrm{~m}$ in vertical change) protruding through the soft substrate surrounding the rocky banks. Between the boulders at the margins and also observed accumulating in crevices on the high-relief granite is thin unconsolidated sand and gravel. The overall impression is a marine landscape of eroded granite often seen in terrestrial environments where onionskin weathering creates a surface of domes in patterns related to joint spacing in the bedrock.

The 'deep reef' biological facies associated with the highrelief granite, derives its name from the deep reef habitat described in other hard-ground environments in south-east Australia (Underwood et al. 1991; Andrew and O'Neill 2000).
This consistent and recognisable habitat of subtidal rock substrate along the NSW coast is characterised by large sponges not found at shallower depths and by reduced densities of algae, particularly phaeophytes (Underwood et al. 1991). Other sessile fauna found on deep reef habitats, in waters deeper than $30 \mathrm{~m}$ are ascidians, cnidarians and bryozoans (Andrew 1999). Underwater video footage from the present study reveals a structurally complex surface of crevices and steep slopes, which is densely covered in erect large and small sponges, and encrusting calcareous red algae. Encrusting red algae are usually the greatest occupier of space due to tolerance of low light conditions ( $<1 \%$ of surface) at these depths (Andrew 1999). Mobile benthos observed were crinoids within crevices and the black sea urchin (Centrostephanus rodgersii) in low numbers on high slope surfaces.

The 'urchin barrens' biological facies is a biologically modified 'deep reef' facies, also observed on the high-relief granite of New Zealand Star Bank. It too derives its name from a consistent habitat found on NSW subtidal rock substrate called a 'barrens habitat' (Underwood et al. 1991). This habitat is characterised by large numbers of the herbivorous black sea urchin (Centrostephanus rodgersii), which graze the surrounding rock substrate (Underwood et al. 1991). Andrew and O'Neill (2000) stated that the urchins are able to maintain their habitat clear of kelp and large macroalgae. The boundaries of urchin barrens are usually distinct, but they are patchy and are not depth related (Underwood et al. 1991). Underwater video footage from the present study revealed large numbers $\left(\sim 10\right.$ to $\left.14 \mathrm{~m}^{-2}\right)$ of Centrostephanus rodgersii on low-relief granite outcrop. Where urchins were concentrated, sessile fauna was rare or absent and the rock was mostly crustose red algae. In places where the numbers of urchins were low, small erect sponges and sea whips (Primnoella australasiae) were observed. This species of sea whip is common on deep rocky banks around south-eastern Australia (Edgar 1997). It is possible that where urchins do not graze heavily, sessile animals with small surface area attachment points, such as sea whips or small sponges, are able to maintain space (Andrew 1999). The density of transects in our study could not differentiate the extent of the "urchin barrens' within the 'deep reef' facies, but is expected to be patchy over the rocky substrate, as found in other surveys (Curley et al. 2002; Hill et al. 2003).

Another consideration of New Zealand Star Bank is the shallow minimum depth $(\sim 10 \mathrm{~m})$ that the largest granite outcrop rises to. No video footage was obtained at the shallowest area, but the physical environment may indicate the type of biological communities found there. Crevices and joints are evident in the shallow area that was ensonified by the multibeam sonar. The shallow depth is within the influence of wind-induced waves and relatively high light compared to surrounding deeper seabed. Off the south-east Australian coast, crayweed (Phyllospora comosa) is the most common large algae in shallow water along exposed rock substrate 
(Edgar 1997). In southern NSW waters, dense forests of crayweed are recognised as a distinct habitat, called Phyllospora forests (Andrew 1999), and we predict that this biological community is found on New Zealand Star Bank in depths shallower than $20 \mathrm{~m}$ (Fig. 8).

\section{'Low-relief sandstone' and 'patchy large sponges'}

The 'low-relief sandstone' secondary biotope represents the two bands of the Broken Reef parallel dune ridges in the north-west of the survey area, which abut the northern granite outcrops. The presence of medium-grained quartz sandstone particles in sediment samples from this area is consistent with the idea that the dune ridges are a quartz arenite of aeolian origin (Jones and Davies 1983). The overall impression is a marine landscape comprising linear ridges of sandstone $\sim 70 \mathrm{~m}$ apart and $\sim 1 \mathrm{~m}$ high, with crests that are eroded and which extend over $5 \mathrm{~km}$ beyond the limit of the survey area (Fig. 1b). The dunes are covered with a thin layer of quartzose sand with minor biogenic gravel.

If the parallel ridges are aeolian dunes formed along a palaeo-coastline (Jones and Davies 1983; Bax and Williams 2001), then the water depth at the base of the dunes is an indication of sea level during the period when the dunes were formed (if proximal to the shoreline). The water depth at the base of the dunes lies at $\sim 65 \mathrm{~m}$ to $75 \mathrm{~m}$, suggesting that the dunes were deposited when sea level was at a maximum of between 65 and $75 \mathrm{~m}$ below mean sea level (MSL). An examination of eustatic sea-level curves shows that in the Late Quaternary, a midstand occurs between 34 and 74 thousand years before present (BP), when sea level was between 65 and $75 \mathrm{~m}$ below MSL (Pillans et al. 1998). This time period represents $\sim 40000$ years of possible coastal dune development. If we also include the period when sea level fell below $65 \mathrm{~m}$ below MSL during the last glacial maximum, when aeolian dunes may have developed distal to the shoreline, then the time period for coastal dune development increases to $\sim 60000$ years. Thus, a substantial period of time is available for the coastal dunes to form along the edge of a midstand coastline.

The 'patchy large sponges' biological facies is strongly associated with this habitat. Underwater video reveals that the dune ridge crests are the preferred habitat of distinct patches of dense and erect large sponges. In contrast, the troughs or relatively flat seabed between the crests have only sparse large sponges growing on the unconsolidated soft substrate. The patches of large erect sponges found on the dune ridge crests are possibly taking advantage of a harder substrate afforded by the sandstone as an attachment surface, and/or increased water flow due to interference of near-seabed currents over the low-relief crests, thus providing favourable conditions for increased densities of these large suspension feeders.

\section{'Quartzose sand' and 'sparse small sponges'}

The 'quartzose sand' secondary biotope correspond to the inner shelf quartzose sands of Ferland and Roy (1997).
They comprise the majority of the seabed of the survey area and are found landward of the approximate 110-m depth contour, and also around the high-relief granite outcrops. Sediment grabs obtained from the predominantly flat and unrippled seabed contained a relatively high proportion of iron-stained, rounded quartz granules. Minor components were biogenic gravel of bryozoan and mollusc shell hash. The relatively mature quartz granules are a result of reworking during successive sea-level fluctuations in a high-energy, wave-dominated environment (Ferland and Roy 1997). In the present survey, no ripples were observed on the flat seabed, which is generally deeper than $65 \mathrm{~m}$ and at the limit of waveinduced mobilisation of sediment (Porter-Smith et al. 2004).

An examination of the bathymetry model revealed that the 'quartzose sand' biotope is slightly raised due to a variety of low-relief geomorphic features. On the eastern side of the granite outcrops are located sediment lobes 2 to $3 \mathrm{~m}$ high that stretch linearly away from the rocky bank. The sediment lobes are probably formed as a result of near-seabed currents sweeping over the bank in a north-easterly direction. Our interpretation is that the lobes are the result of a currentinduced, bottom stress maxima around the prominent edges of the bank, such as occur in other current-scoured environments (Stride 1982; Harris et al. 1995). The prevailing north-easterly flowing currents in the area are considered to be generated from coastal trapped waves (CTWs) propagating northward along the Gippsland coast (Morrow et al. 1990; Harris et al. 1991). Another geomorphic feature that influences the relief of the seabed in this biotope are the small areas of granite subcrop, which appear as raised seabed in between the high-relief granite outcrop and parallel dune ridges, and also among the sediment lobes. The seabed comprises quartzose sand as a layer over the granite subcrop, and underwater video reveals an irregular seabed with low-relief, which is likely due to the morphology of the granite lying just below the seabed.

The 'sparse small sponges' biological facies is associated with the 'quartzose sand' secondary biotope. Video footage shows this facies to comprise mostly low numbers of individual small sponges. The flat seabed of the study area tends to have low densities of erect small fan sponges or rare large finger sponges that occur at an average distance of $\sim 10 \mathrm{~m}$ apart. Encrusting sponges were not observed. An important variation to the predominantly sparse small sponges observed on flat seabed is that wherever the seabed became irregular or rises in low-relief, then these localised areas corresponded with an increase in numbers of large sponges. Similarly, wherever low-relief rounded granite boulders protruded through the quartzose sand, then concentrations of large finger sponges dominated the sessile fauna on the irregular seabed. Another interesting feature of this facies were the accumulation of dead New Zealand screw shells (Maoricolpus roseus) observed in the underwater video taken in the north of the survey area in water depths of $\sim 70 \mathrm{~m}$. Numbers of these large 
(up to $87 \mathrm{~mm}$ in length) gastropods were $\sim 30 \mathrm{~m}^{-2}$; however, living $M$. roseus were not observed in the video but may well have been infauna in this area. This introduced gastropod has a recorded expansion along the south-east Australian coast and is known for its ability to considerably modify the habitat in which it lives (Allmon et al. 1994; Bax et al. 2003). We were unable to resolve the extent of the substrate covered by these gastropods with our video transects.

\section{'Muddy sand' and 'bioturbate'}

The 'muddy sand' secondary biotope is defined as seaward of the approximate $110-\mathrm{m}$ depth contour where the seabed deepens rapidly away from New Zealand Star Bank and flattens out in depths of $\sim 125 \mathrm{~m}$. Interestingly, the 110-m depth contour is also the approximate lowstand for eustatic sea level during the last glacial maximum (Fleming et al. 1998). Therefore, at $\sim 19000$ to 22000 years ago, when sea level had dropped to $\sim 110 \mathrm{~m}$ below MSL (Yokoyama et al. 2000), the coastline in this region would have been close to this biotope boundary. New Zealand Star Bank would have appeared as a prominent granite hill at the shoreline. Today, sediments in this biotope are more muddy, with fine to very fine sand, and correspond to the mid-shelf muddy sands of Ferland and Roy (1997). The transition to finer-grained sand and increased mud content just seaward of New Zealand Star Bank was observed in the underwater video of the area, and from the results of Jones and Davies (1983). The proportion of mud is higher due to the seaward transport of fine-grained sediment from the high-energy inner to middle shelf (Morrow et al. 1990).

The 'bioturbate' biological facies associated with the 'muddy sand' biotope is quite different to the biological communities found on the inner shelf landward of the 110-m depth contour. Underwater video in the present survey revealed relatively few sessile fauna, except for rare octocorals; however, burrows from infaunal biota were clearly more noticeable compared to the shallower transects. Despite the fact that we were unable to sample for soft-bodied infauna using grabs, this facies is named for the unseen infauna that were evidenced by the numerous burrows, and which appear to dominate seaward of the bank. In this deeper environment the light level is relatively low and the seabed is well below storm wave base (Porter-Smith et al. 2004).

\section{Discussion}

\section{Geology-benthos relationships}

We believe the descriptions and maps of the secondary biotopes and biological facies address the aims of this study and provide insights into the possible relationships between the geology of the seabed and the associated biological communities on this temperate rocky bank. By characterising the benthic habitats at the secondary biotope and biological facies levels we can gain a better understanding of the controls on benthic biodiversity. The goal is to systematically understand the relationships between seabed characteristics and associated biological communities at the site $(<10 \mathrm{~km})$ scale. An important question asked earlier in this paper is whether geological data can be mapped as a proxy to predict the occurrence of assemblages of benthic organisms. The major differences which control the distribution of biological communities in the New Zealand Star Bank area appear to be related to variations in substrate: (1) hard-ground features related to granite outcrops; (2) unconsolidated sediment on a flat seabed; and (3) unconsolidated sediment on a low-relief seabed.

\section{Hard-ground features related to granite outcrops}

It is evident in the present study that there is a vast difference between communities that live on hard-ground features, such as the granite outcrops of New Zealand Star Bank, and those that exist on soft substrate surrounding the rocky bank. These granite outcrops support a diverse sessile fauna of large and small sponges, bryozoans, hydroids and ascidians that prefer stable attachment surfaces (Underwood et al. 1991; Andrew 1999; Andrew and O’Neill 2000). Finer-scale ecological niches of the granite outcrops are the high-relief fractures and joints that provide numerous microhabitats for the diverse mobile fauna observed in this study. Another important physical-biological relationship is the prey availability, which is dependent on broader-scale hydrodynamic conditions. Substratum heterogeneity that interferes with current flow pattern will increase water turbulence and enhance particle capture by benthic suspension feeders (Gili et al. 2001). The dense cover of suspension feeders suggests that the availability of food particles is sufficiently high within the relatively strong currents passing over these high-relief habitats to support a rich and colourful sessile fauna. At a finer scale, biotic factors, such as competition for space, predation and larval settlement, would also influence the distribution of benthos on subtidal rocky substrate (Edgar 2001).

Deep reef habitats can also be biologically modified by grazing urchins to produce patchy urchin barrens. In the present study, dense aggregations of Centrostephanus rodgersii reduced the sessile fauna to low numbers of sea whips and small sponges. This resulted in granite outcrop covered in crustose red algae and devoid of foliose algae and large sessile fauna. In temperate waters, large aggregations of these urchins can graze over extensive areas, sometimes in patches large enough to cover several hectares and with boundaries that are always clear (Andrew and O'Neill 2000; Vanderklift and Kendrick 2004). This urchin species has a preference for habitat complexity, occupying crevices during the daytime and emerging at night to graze, travelling up to $5 \mathrm{~m}$ from the crevice to forage (Hill et al. 2003; Vanderklift and Kendrick 2004). Thus the fractures and joints of the granite outcrops of New Zealand Star Bank provide an ideal resting habitat for the black sea urchin. Underwater video in this survey also shows urchins on the upper surfaces of granite outcrop during 
the day, as has been observed in other studies (Andrew and O’Neill 2000).

\section{Unconsolidated sediment on a flat seabed}

Unconsolidated sediment habitats in deeper water have not received the same research attention as shallow water hard-ground features (Malatesta and Auster 1999). However, several habitat studies have been conducted over the soft substrate in south-eastern Australia (Coleman et al. 1997; Bax and Williams 2001; Kloser et al. 2001; Ferns and Hough 2002). In the present study, unconsolidated sediments landward of the approximate 110-m contour are a quartzose sand with variable amounts of biogenic gravel of bryozoans and molluscs. The quartz grains are relatively mature and subrounded and the high iron staining suggests reworking during successive sea-level fluctuations (Ferland and Roy 1997). This sediment type covers the mostly flat seabed of the inner Gippsland Shelf (Jones and Davies 1983; Bax and Williams 2001). This habitat supports a biological community of sparse small bushy sponges and the occasional large finger sponge as sessile fauna. Rare solitary ascidians, infaunal anemones and small bryozoans were also present on the flat sandy seabed.

Mobile fauna observed in this habitat included hermit crabs and octopuses and, in the north of the survey area, aggregations of dead Maoricolpus roseus. This gastropod was first recorded in Tasmanian waters in the early 1960s and has subsequently spread across the Bass Strait to the Victorian and NSW coasts to depths of $80 \mathrm{~m}$ (Bax et al.2003). Museum Victoria records show that this species was off East Gippsland by 1990 (Passlow et al. 2004). Bax and Williams (2001) also report occasional $M$. roseus beds of intermediate to sparse density within the soft substrate of the nearby Point Hicks Reef. Dense beds of these burrowing and suspension-feeding gastropods have the ability to dominate the benthic community in unconsolidated sediments within its geographic distribution; however, it is unclear whether the beds of $M$. roseus are having a negative effect on native species on the south-east Australian shelf (Bax et al. 2003). The gastropod prefers a firm coarse substrate and a moderate to strong current, which provides available suspended food but does not have a large suspended terrigenous load (Allmon et al. 1994; Bax et al. 2003). The physical environment of the unconsolidated sediment and flat seabed landward of New Zealand Star Bank is therefore quite suitable for the occurrence of this species.

On the middle shelf and seaward of the approximate $110-\mathrm{m}$ depth contour, the seabed becomes relatively flat and muddy. Sediments correspond to the mid-shelf muddy sands of Ferland and Roy (1997), and the higher mud component is due to the seaward transport of fine-grained sediment from the high-energy inner to middle shelf (Morrow et al. 1990). The carbonate content of the sediment is also higher on middle shelf compared to the inner shelf, and increases across the shelf due to the bioerosion of relict carbonate skeletal debris
(Jones and Davies 1983; Ferland and Roy 1997). This finergrained and flat habitat supports a community dominated by infauna, resulting in moderate bioturbation observed as numerous burrows. Animals that push through soft sediments with body widths up to $10 \mathrm{~mm}$, which might result in burrows, include amphipods, callianassid shrimps, bivalves and polychaetes (Edgar 2001). This study was unable to determine the infauna producing the burrows. Sessile fauna observed were rare individual octocorals upright on the flat seabed. This habitat is relatively stable in terms of low light and the lack of wave-induced currents at this depth, and clearly favours infauna over sessile fauna.

\section{Unconsolidated sediment on a low-relief seabed}

A striking observation in this study was the increase in density and sizes of sponges wherever any low-relief feature appeared on the relatively flat seabed. The 5-m pixel bathymetric model was able to resolve many low-relief features around New Zealand Star Bank. Underwater video confirmed the patches of large sponges occupying these features and helped explain the origin of the low-relief features. These features may take the form of sediment lobes that stretch linearly away from the rocky bank, raised seabed due to granite subcrop influencing the morphology of the overlying soft substrate, or long ridges of sandstone with a thin cover of unconsolidated sediment. Within the limits of this study, there appears to be no difference in the preference of certain sponge morphologies to favour one type of low-relief feature over another, therefore we believe that the common factor is that the large sponges prefer areas that are elevated above the surrounding flat seabed. Again, hydrodynamic factors are likely to be important. Interference in the flow of water caused by irregularities in the seabed leads to a concentration near the seabed of food and passively dispersing invertebrates (Edgar 2001). These environmental conditions would favour the development of populations of sponges because the increased turbulence enhances particle capture by these suspension feeders (Gili et al. 2001).

In the present study, the patchy distribution of large sponges on low-relief features is closely related to proximity to New Zealand Star Bank. Small areas of raised seabed due to granite subcrop are clustered around the high-relief granite outcrops, and do not appear to extend beyond several kilometres of the bank before grading into the relatively flat seabed. Similarly, the 2 to $3 \mathrm{~m}$ high sediment lobes do not appear to extend for more than a kilometre to the north-east of the bank, because the current scouring caused by near-seabed currents reduce in bottom stress with distance from the highrelief granite outcrops. Thus, patches of large sponges on unconsolidated soft substrate are likely to be more concentrated closer to the bank as the seabed becomes more irregular and raised. In contrast, the long ridges of sandstone comprising Broken Reef can be traced for many kilometres across our study area, and is known to extend for tens of kilometres 
south-west along the East Gippsland shelf (Fig. 1b). Thus, the biological community of patchy large sponges associated with this biotope is predicted to cover a significant area of the shelf wherever Broken Reef can be mapped. Bax and Williams (2001) highlighted the vulnerability of low-relief, fossiliferous sandstone banks, such as Broken Reef, to damage by bottom trawling. Once eroded these low-relief reefs may never recover their structural habitat.

\section{Fish-benthos relationships}

This study also provides useful links between fish and associated benthic habitats, and have been the subject of previous investigations on this shelf(Williams and Bax 2001). Habitatrelated patterns are usually the rule rather than the exception for temperate rocky reef fishes (Curley et al. 2002). Based on fish-benthos relationships found on the high-relief granite at the nearby Point Hicks Reef (Bax and Williams 2001; Williams and Bax 2001), New Zealand Star Bank should support planktivorous Butterfly perch (Caesioperca lepidoptera) and Eastern orange perch (Lepidoperca pulchella), and the carnivorous Port Jackson shark (Heterodontus portusjacksoni) and Draughtboard shark (Cephaloscyllium laticeps). Indeed, our underwater video showed a Draughtboard shark cruising above the crevices of high-relief granite outcrop as well as cloud-like schools of Butterfly perch feeding on plankton in the water column above the bank. During the period of the survey, large numbers of seals were also observed feeding over the bank, presumably on the shoals of bentho-pelagic fish observed in the video. These seals were likely Australian fur seals (Arctocephalus pusillus) due to the proximity to a known haul-out site on nearby Gabo Island and their foraging distribution (Andrew 1999). The presence of these higher-level predators demonstrates the importance of New Zealand Star Bank as a significant location for food in the eastern Bass Strait.

\section{Assessment techniques}

The assessment techniques shown in this survey reveal quite different levels of resolution ( $1 \mathrm{~cm}$ up to $5 \mathrm{~m}$ ), and making the link between these various spatial scales and the differing technologies is difficult (Malatesta and Auster 1999). It is only through the use of GIS techniques that oceanic themes of varying scale can be mapped within a common position datum and easily compared with each other. The ability of GIS to present high-resolution bathymetric models as a 3D DTM, which can then be draped with thematic layers representing physical and biological datasets, is indispensable for scientists and managers of marine environments. Similarly, a new age of ocean exploration is underway with the use of multibeam sonar systems that can fully ensonify the seabed and provide an unprecedented view of the true complexity of the seafloor (Exon and Hill 1999; Kostylev et al. 2001; Harris et al. 2004). In this study, the real-time mapping of the seabed with multibeam sonar permitted considered and targeted groundtruthing so that we could add value to what was primarily a safe navigation survey by the RAN.

The assessment techniques used in this study are recommended for future ocean mapping studies. Multibeam sonar data was most useful for revealing the high-resolution geomorphic features of the seabed. Co-registered backscatter data and bathymetry models alone can provide most of the information to characterise the geomorphology of the seabed. In the present survey, slope models derived from the bathymetric model were also useful for helping delineate the boundaries of various features. However, only underwater video, at the resolution of centimetres to metres, could provide the groundtruthing to observe the contrast between a diverse and colourful benthos on high-relief granite and the relatively sparse small sponges on unconsolidated soft substrate. Single long video transects are recommended because biological assemblages can be very patchy on the seabed (Starmans and Gutt 2002; Stevens 2005). In this study, the composition of sediment grabs, at the resolution of centimetres, were not able to discriminate benthic assemblages at this scale because of the disconnection between the environment for existing biota and the hydrodynamic sorting of their skeletal remains until equilibrium is reached (Jones and Davies 1983). Nevertheless, the examination of sediment composition was useful in helping to explain the environment of deposition.

Therefore, each technique by itself has its merits and disadvantages. However, the combination of assessment techniques using multibeam sonar mapping, underwater video and sediment grabs complement each other and provide powerful tools to characterise the seabed. The integration of high-resolution bathymetry and dense and well targeted groundtruthing was the key to understanding the relationships between seabed characteristics and associated biological communities at the site $(<10 \mathrm{~km})$ scale. As MPAs often rely on abiotic or geophysical factors to map the distribution of benthic biodiversity, our findings add confidence for the use of high-resolution geological datasets to provide a basis for reserve selection.

In conclusion, multibeam sonar mapping has revealed $\sim 100 \mathrm{~km}^{2}$ of complex physiography on and around New Zealand Star Bank in the eastern Bass Strait at a detail not observed previously. Extensive groundtruthing of the area provided grab samples and underwater video transects. In this study, we characterised the seabed of the study area, adopting the benthic habitat classification scheme used for the bioregionalisation of Australia (Butler et al. 2001). The spatial boundaries of secondary biotopes and biological facies at the site $(<10 \mathrm{~km})$ scale were defined on the basis of geomorphology revealed by the bathymetry model and the results of statistical analysis of the sediment and video transect data. Four secondary biotopes were observed: (1) highrelief granite; (2) low-relief sandstone; (3) quartzose sand; and (4) muddy sand. The biological facies associated with 
these biotopes were: (1) deep reef/urchin barrens; (2) patchy large sponges; (3) sparse small sponges; and (4) bioturbate.

This study also explored whether geological data can be mapped as a proxy to predict the occurrence of assemblages of benthic organisms. The major differences that control the distribution of biological communities in the New Zealand Star Bank area appear to be related to variations in substrate as follows.

(1) Hard-ground features related to high-relief granite outcrops are associated with diverse and abundant sessile and motile fauna. These faunal communities may be biologically modified to patchy barrens habitat by grazing urchins.

(2) Unconsolidated sediment on a flat seabed is associated with sparse small sponges on the inner shelf. On the middle shelf and seaward of bank, the flat and muddy seabed supports a community dominated by infauna.

(3) Unconsolidated sediment on a low-relief seabed is associated with an increase in the density and sizes of sponges concentrated on any low-relief feature raised above the surrounding flat seabed.

The successful management of the East Gippsland shelf environment requires that decisions are made based on an understanding of the characteristic physical and biological structure and processes. We have provided habitat maps of the seabed around New Zealand Star Bank at a high-resolution and examined the possible relationships between the geology of the seabed and the associated biological communities on this temperate rocky bank. New Zealand Star Bank and the adjacent Broken Reef is representative of a diverse range of habitats supporting prolific benthic and pelagic communities in apparently pristine condition, and may provide a useful example for the selection of habitats suitable for inclusion in a marine protected area.

\section{Acknowledgments}

We thank CMDR John Maschke and the crew of HMAS Melville for their professionalism and assistance in conducting this survey and hosting R.J.B. and J.J.D. for the period of the voyage. We thank H. Gary Greene and two anonymous reviewers for their thorough review and constructive criticism of the manuscript. R.J.B. acknowledges a PhD scholarship through the School of Geography and Environmental Studies at the University of Tasmania. J.J.D. and P.T.H. publish with the permission of the Chief Executive Officer, Geoscience Australia.

\section{References}

AHO (1971). 'AUS358-Wilsons Promontory to Point Hicks and Flinders Island (Eastern Sheet).' (Australian Hydrographic Service: Wollongong.)
Allmon, W. D., Jones, D. S., Aiello, R. L., Gowlett-Holmes, K., and Probert, P. K. (1994). Observations on the biology of Maoricolpus roseus (Quoy and Gaimard) (Prosobranchia: Turritellidae) from New Zealand and Tasmania. The Veliger 37, 267-279.

Andrew, N. L. (1999). 'Under Southern Seas.' (University of New South Wales Press: Sydney.)

Andrew, N. L., and O'Neill, A. L. (2000). Large-scale patterns in habitat structure on subtidal rocky reefs in New South Wales. Marine and Freshwater Research 51, 255-263. doi:10.1071/MF99008

Bax, N. J., and Williams, A. (2001). Seabed habitat on the south-eastern Australian continental shelf: context, vulnerability and monitoring. Marine and Freshwater Research 52, 491-512. doi:10.1071/ MF00003

Bax, N. J., Kloser, R., Williams, A., Gowlett-Holmes, K., and Ryan, T. (1999). Seafloor habitat definition for the spatial management in fisheries: a case study on the continental shelf of southeast Australia. Oceanologica Acta 22, 705-720. doi:10.1016/S03991784(00)88961-6

Bax, N. J., Burford, M., Clementson, L., and Davenport, S. (2001). Phytoplankton blooms and production sources on the south-east Australian continental shelf. Marine and Freshwater Research 52, 451-462. doi:10.1071/MF00001

Bax, N. J., McEnnulty, F. R., and Gowlett-Holmes, K. L. (2003). Distribution and biology of the introduced gastropod, Maoricolpus roseus (Quoy and Gaimard, 1834) (Caenogastropoda: Turritellidae) in Australia. Technical Report No. 25. CSIRO Marine Research, Centre for Research on Introduced Marine Pests, Hobart.

Butler, A., Harris, P. T., Lyne, V., Heap, A., Passlow, V., and Smith, R. (2001). An interim, draft bioregionalisation for the continental slope and deeper waters of the South-East Marine Region of Australia Report to the National Oceans Office. CSIRO Marine Research, Geoscience Australia, Hobart.

Clarke, K. R. (1993). Non-parametric multivariate analyses of changes in community structure. Australian Journal of Ecology $\mathbf{1 8}$ $117-143$.

Clarke, K. R., and Warwick, R. M. (2001). 'Change in Marine Communities: An Approach to Statistical Analysis and Interpretation.' 2nd edn. (PRIMER-E: Plymouth, UK.)

Coleman, N., Gason, A. S. H., and Poore, G. C. B. (1997). High species richness in the shallow marine waters of south-east Australia. Marine Ecology Progress Series 154, 17-26.

Coney, P. J., Edwards, A., Hine, R., Morrison, F., and Windrim, D. (1990). The regional tectonic of the Tasman orogenic system, eastern Australia. Journal of Structural Geology 12, 519-543. doi:10.1016/0191-8141(90)90071-6

Curley, B. G., Kingsford, M. J., and Gillanders, B. M. (2002). Spatial and habitat-related patterns of temperate reef fish assemblages: implications for the design of Marine Protected Areas. Marine and Freshwater Research 53,1197-1210. doi:10.1071/MF01199

DEH (2003). Australia's south-east marine region: a user's guide to identifying candidate areas for a regional representative system of marine protected areas. Department of the Environment and Heritage. Available online at: http://www.deh.gov.au/coasts/mpa/commonwealth/ identifying/index.html, verified August 2005.

DNRE (1999). 'SJ 55-8: Mallacoota 1:250,000 Geological Map Series.' (Department of Natural Resources and Environment: Melbourne.)

Edgar, G. J. (1997). 'Australian Marine Life: the Plants and Animals of Temperate Waters.' (Reed Books: Melbourne.)

Edgar, G. J. (2001). 'Australian Marine Habitats in Temperate Waters.' (Reed New Holland: Sydney.)

Exon, N., and Hill, P. (1999). Seabed mapping using multibeam swathmapping systems: an essential technology for mapping Australia's margins. AGSO Journal of Australian Geology \& Geophysics 17, $1-16$. 
Ferland, M. A., and Roy, P. S. (1997). Southeastern Australia: a sea-level dependent, cool-water carbonate margin. In 'Cool-water Carbonates'. (Eds N. P. James and J. D. A. Clarke.) (SEPM Society for Sedimentary Geology: Tulsa, OK.)

Ferns, L. W., and Hough, D. (2002). High resolution marine habitat mapping of the Bunurong Coast (Victoria) - including the Bunurong Marine and Coastal Park. Parks, Flora and Fauna Division, Department of Natural Resources and Environment, Melbourne.

Fleming, K., Johnston, P., Zwartz, D., Yokoyama, Y., Lambeck, K., and Chappell, J. (1998). Refining the eustatic sea-level curve since the Last Glacial Maximum using far- and intermediate-field sites. Earth and Planetary Science Letters 163, 327-342. doi:10.1016/S0012821X(98)00198-8

Folk, R. T. (1954). The distinction between grain size and mineral composition in sedimentary-rock nomenclature. Journal of Geology 62 , 344-359.

Gili, J.-M., Coma, R., Orejas, C., Lopez-Gonzalez, P. J., and Zabala, M. (2001). Are Antarctic suspension-feeding communities different from those elsewhere in the world? Polar Biology 24, 473-485. doi: $10.1007 / \mathrm{S} 003000100257$

Harris, P. T., Baker, E. K., and Cole, A. R. (1991). Physical sedimentology of the Australian continental shelf - with emphasis on Late Quaternary deposits in major shipping channels, port approaches and choke points. Report No. 51. Ocean Sciences Institute, Sydney.

Harris, P. T., Pattiaratchi, C. B., Collins, M. B., and Dalrymple, R. W. (1995). What is bedload parting? In 'Tidal Signatures in Modern and Ancient Sediments'. (Eds B. W. Flemming and A. Bartholoma.) pp. 3-18. (International Association of Sedimentologists: Durham, UK.)

Harris, P. T., Radke, B., Smith, A., Glen, K., Rollet, N., Exon, N. F., and Passlow, V. (2000). Marine geological data collected during Southern Surveyor Voyage 01/00: eastern Bass Strait and Great Australian Bight. Record 2000/43. Geoscience Australia, Canberra.

Harris, P. T., Heap, A. D., Wassenberg, T., and Passlow, V. (2004). Submerged coral reefs in the Gulf of Carpentaria, Australia. Marine Geology 207, 185-191. doi:10.1016/J.MARGEO.2004.03.002

Hill, N. A., Blount, C., Poore, A. G. B., Worthington, D., and Steinberg, P. D. (2003). Grazing effects of the sea urchin Centrostephanus rodgersii in two contrasting rocky reef habitats: effects of urchin density and its implications for the fishery. Marine and Freshwater Research 54, 691-700. doi:10.1071/MF03052

IMCRA (1998). Interim marine and coastal regionalisation for Australia: an ecosystem-based classification for marine and coastal environments, Version 3.3. Environment Australia, Commonwealth Department of Environment, Canberra

Jones, H. A., and Davies, P. J. (1983). Superficial sediments of the Tasmanian continental shelf and part of Bass Strait. BMR Bulletin 218.

Kloser, R. J., Bax, N. J., Ryan, T., Williams, A., and Barker, B. A. (2001). Remote sensing of seabed types in the Australian South East Fishery; development and application of normal incident acoustic techniques and associated 'ground truthing'. Marine and Freshwater Research 52, 475-489. doi:10.1071/MF99181

Kostylev, V. E., Todd, B. J., Fader, G. B. J., Courtney, R. C., Cameron, G. D. M., and Pickrill, R. A. (2001). Benthic habitat mapping on the Scotian Shelf based on multibeam bathymetry, surficial geology and sea floor photographs. Marine Ecology Progress Series 219, $121-137$

Lavering, I. H. (1994). Marine environments of Southeast Australia (Gippsland Shelf and Bass Strait) and the impact of offshore petroleum exploration and production activity. Marine Georesources and Geotechnology 12, 201-226.

Malatesta, R. J., and Auster, P. J. (1999). The importance of habitat features in low-relief continental shelf environments. Oceanologica Acta 22, 623-626. doi:10.1016/S0399-1784(00)88953-7
Middleton, J. F., and Black, K. P. (1994). The low frequency circulation in and around Bass Strait: a numerical study. Continental Shelf Research 14, 1495-1521. doi:10.1016/0278-4343(94)90087-6

Morrow, R. A., Jones, I. S. F., Smith, R. L., and Stabeno, P. J. (1990). Bass Strait forcing of coastal trapped waves: ACE revisited. Journal of Physical Oceanography 20, 1528-1538. doi:10.1175/15200485(1990) $020<1528:$ BSFOCT $>2.0 . C O ; 2$

NOO (2002). Ecosystems - nature's diversity - the South-east Regional Marine Plan. National Oceans Office (NOO), Hobart.

NOO (2004). South-east Regional Marine Plan, implementing Australia's Oceans Policy in the south-east marine region. National Oceans Office (NOO), Hobart.

Passlow, V., O’Hara, T., Daniell, J., and Beaman, R. J. (2004). Sediments and benthic biota of Bass Strait: an approach to benthic habitat mapping. Record 2004/23. Geoscience Australia, Canberra.

Pillans, B., Chappell, J., and Naish, T. R. (1998). A review of the Milankovitch climate beat: template for Plio-Pleistocene sea-level changes and sequence stratigraphy. Sedimentary Geology 122, 5-21. doi:10.1016/S0037-0738(98)00095-5

Porter-Smith, R., Harris, P. T., Anderson, O. B., Coleman, R., Greenslade, D., and Jenkins, C. J. (2004). Classification of the Australian continental shelf based on predicted sediment threshold exceedance from tidal currents and swell waves. Marine Geology 211, 1-20.

RAN (2002). New Zealand Star Bank. Royal Australian Navy Summary Report of Survey HI 339G: HMAS MELVILLE Cruise, October 2001. Australian Hydrographic Office, Wollongong.

Roff, J. C., Taylor, M. E., and Laughren, J. (2003). Geophysical approaches to the classification, delineation and monitoring of marine habitats and their communities. Aquatic Conservation. Marine and Freshwater Ecosystems 13, 77-90. doi:10.1002/ AQC.525

Starmans, A., and Gutt, J. (2002). Mega-epibenthic diversity: a polar comparison. Marine Ecology Progress Series 225, 45-52.

Stevens, T. (2002). Rigor and representativeness in marine protected area design. Coastal Management 30, 237-248. doi:10.1080/ 08920750290042183

Stevens, T. (2005). Scales of similarity in soft sediment epibenthic assemblages: implications for marine protected area design. Marine Biology 146, 345-354. doi:10.1007/S00227-004-1454-Z

Stride, A. H. (1982). 'Offshore Tidal Sands - Processes and Deposits.' (Chapman and Hall: London.)

Underwood, A. J., Kingsford, M. J., and Andrew, N. L. (1991). Patterns in shallow subtidal marine assemblages along the coast of New South Wales. Australian Journal of Ecology 6, 231-249.

Vanderklift, M. A., and Kendrick, G. A. (2004). Variation in abundances of herbivorous invertebrates in temperate subtidal rocky reef habitats. Marine and Freshwater Research 55, 93-103. doi:10.1071/MF03057

Williams, A., and Bax, N. J. (2001). Delineating fish-habitat associations for spatially based management: an example from the south-eastern Australian continental shelf. Marine and Freshwater Research 52, 513-536. doi:10.1071/MF00017

Yokoyama, Y., Lambeck, K., De Deckker, P., Johnston, P., and Fifield, L. K. (2000). Timing of the Last Glacial Maximum from observed sea-level minima. Nature 406, 713-716. doi:10.1038/35021035

Young, J. W., Bradford, R., Lamb, T. D., Clementson, L. A., Kloser, R., and Galea, H. (2001). Yellowfin tuna (Thunnus albacares) aggregations along the shelf break off south-eastern Australia: links between inshore and offshore processes. Marine and Freshwater Research 52, 463-474. doi:10.1071/MF99168

Manuscript received 31 December 2004; revised 27 April 2005; and accepted 2 June 2005. 